\title{
Assessment of thermal environmental conditions and quantification of thermal adaptation in naturally ventilated buildings in composite climate of India
}

\author{
Shivraj Dhaka ${ }^{\mathrm{a}}$, Jyotirmay Mathur ${ }^{\mathrm{a}, 1}$, Gail Brager $^{\mathrm{b}}$, Anoop Honnekari ${ }^{\mathrm{b}}$ \\ Department of Mechanical Engineering, Malaviya National Institute of Technology Jaipur, India. \\ Center for Built Environment, University of California, Berkeley.
}

\begin{abstract}
India has diverse climatic conditions and study of adaptation can play important role for defining thermal comfort conditions in naturally ventilated buildings. Therefore, a field study of thermal comfort was carried out in thirty well ventilated residential and office buildings in composite climate region of India. The objective of the study is to evaluate the thermal environmental conditions and quantify thermal adaptation for occupants of these buildings.
\end{abstract} The study ascertains thermal neutrality and thermal acceptability and compares adaptation with field studies referred by a pool of researchers and scientists. The methodology of the study was through questionnaire administered to building occupants to record sensations and preferences for thermal environment variables. Simultaneously, physical measurements of environment variables were recorded considering class-II protocol of field measurements. During the study, the responses collected were 1811. The comfort temperature of the group was $27.21{ }^{\circ} \mathrm{C}$ for all seasons. The effects of seasonal variations on neutral temperature were also determined; respondents felt neutral at $25.6{ }^{\circ} \mathrm{C}, 27.0{ }^{\circ} \mathrm{C}$ and $29.4{ }^{\circ} \mathrm{C}$ during winter, moderate and summer seasons, respectively. Acceptable humidity and air velocity were $36 \%$ and $0.44 \mathrm{~m} / \mathrm{s}$ for all seasons. Thermal acceptability for $90 \%$ and $80 \%$ were higher than the limits defined by comfort standards. Thermal acceptability reflected that study subjects were more adaptive to the thermal environment. The study observed that heat balance model of thermal comfort overestimated and underestimated thermal sensation during warm and cool

\footnotetext{
${ }^{1}$ Corresponding author: Prof. Jyotirmay Mathur, Head-Center for Energy and Environmnet, MNIT Jaipur, India. Email: jyotirmay.mathur@gmail.com; Phone: +91-9414250329
} 
thermal conditions, respectively. Furthermore, the study determines relationship between room temperature and comfort temperature with outdoor conditions.

Keywords: Naturally ventilated buildings; Thermal environment; Thermal neutrality; Thermal adaptation; Comfort temperature

\section{Introduction}

Unconditioned buildings are of great interest to designers, architects, and building owners due to less energy use compared to air-conditioned buildings throughout the building's life span. Occupants from naturally ventilated buildings encounter variable environment throughout the daytime and use available controls to make their indoor environment thermally comfortable [1]. Thermal comfort is defined as 'that condition of mind which expresses satisfaction with the thermal environment and is assessed by subjective evaluation' $[2,3]$. In contemporary thermal comfort research, there are two approaches to developing predictive thermal comfort models, namely a human heat balance approach and adaptive approach. Fanger developed the first human heat balance model for thermal comfort in 1972 based on studies carried out in climate chambers [4]. This model proposed a comfort index such as Predicted Mean Vote-Percentage Predicted Dissatisfied (PMV-PPD) to evaluate the quality of indoor thermal environment. Thermal environment variables include room air temperature, globe temperature, relative humidity, air velocity and the two personal variables of clothing insulation and activity. In addition, researchers and scientists conducted field studies of thermal comfort to define the ranges of acceptable thermal environment for conditioned and unconditioned buildings, which led to development of Adaptive Thermal Comfort (ATC) model. This work was motivated by the need for energy conversation, and extensive anecdotal observations that higher indoor temperatures comfort were frequently acceptable in naturally ventilated buildings. 
Early field studies conducted by Auliciems [5] and Humphreys [6] illustrated the effect of outdoor environment on comfortable indoors and added insights on psychological effects on thermal comfort. An extensive literature review on thermal adaptation carried out by Brager and de Dear reported a distinction in thermal comfort responses in air-conditioned and nonair-conditioned buildings due to a combination of past thermal experience in the buildings and differences in levels of perceived controls [7]. In addition, field studies of comfort analysed by de Dear and Brager described that occupants from different building environments feel neutral at variable temperatures. This indicated the effect of adaptation on thermal comfort [8]. Feriadi and Wong [9] carried out a study for hot and humid tropical climate of Indonesia and demonstrated a neutral temperature of $29.2{ }^{\circ} \mathrm{C}$, and similar field studies performed by Nicol and Roaf for warm climates of Pakistan indicated higher neutral temperature of $30{ }^{\circ} \mathrm{C}$ [10]. Tropical Summer Index (TSI), a study of Indian subjects conducted by Sharma and Ali [11] during the 1980's reported high comfort temperature bandwidth $\left(25-30^{\circ} \mathrm{C}\right)$ as compared to comfort zone suggested by ASHRAE Standard 55. Recent thermal comfort studies from India also indicated that occupants in warm climates perceive thermal satisfaction at higher indoor temperatures [12-15].

The predominant effect of adaptation is reported in the literature for those buildings that are not equipped with Heating, Ventilating and Air-Conditioning (HVAC) systems [7, 16]. Field studies revealed the effect of adaptive factors on thermal comfort and concluded that the heat balance model overestimates and underestimates thermal comfort state during hot and cold sensation of subjects, respectively [17]. Adaptive controls such as operable windows, doors, blinds, curtains, fans \& fan regulator for adjustment of air velocity, and so on help to create a thermally comfortable indoor environment. Use of these adaptive controls are also affected by seasonal and climatic conditions. Occupants from hot \& dry locations may like to use window, door and fan to meet air movement requirements whereas for composite climatic 
conditions, may like to use window and door opening that could provide thermally comfortable conditions. Raja et al. [18] explained that availability and appropriate use of adaptive controls are the key to better performance of the building and improves the state of thermal comfort. A study performed by Nicol and Humphreys [19] described that occupants use adaptive opportunities to achieve desired thermal conditions and also stated that adaptive practice is context dependent [19].

The present study assesses thermal environment conditions and quantifies adaptation in warm climatic zone of India. The study determines thermal neutrality and thermal acceptability for occupants of naturally ventilated buildings. Acceptable humidity level and air velocity are also determined using statistical analysis. The study establishes relationships between comfort temperature with indoor and outdoor temperatures. Furthermore, comparisons of the previous referred studies with the results of present study are analysed to quantify adaptation with respect to Indian subjects.

\section{Methodology}

\subsection{Field study description}

Field studies of thermal comfort were performed in thirty naturally ventilated buildings in Jaipur city $\left(26.82{ }^{\circ} \mathrm{N}, 75.80{ }^{\circ} \mathrm{E}\right.$, and $\left.+390 \mathrm{msl}\right)$, which is categorized as a composite climate of India. Meteorological conditions in this climate vary over a wide range during summer and winter seasons. Summer peak temperature reaches to $45^{\circ} \mathrm{C}$, and then falls to around $4{ }^{\circ} \mathrm{C}$ in winter [20]. The fluctuation of mean monthly outdoor dry bulb temperature in Jaipur varies for more than 180 days (more than six months), and that is why the city is considered under composite climatic zone of India [21].

The present study is conducted in naturally ventilated buildings such as institutes, offices, and hostels. Naturally ventilated or free running buildings are those that have operable windows and no mechanical Heating, Ventilating and Air-Conditioning (HVAC) systems. Among the thirty 
survey buildings, seventeen buildings operated purely on natural ventilation mode whereas thirteen buildings were mixed mode type. Figure 1 shows the photographs of some of the survey buildings. The study buildings were found to be constructed by conventional construction materials such as bricks and stones for walls and Reinforced Cement Concrete (RCC) structure for roof construction, respectively. The conventional roof construction prescribes different construction layer of $100 \mathrm{~mm}$ to $150 \mathrm{~mm}$ RCC slab, cement mortar with sand and gravel of 25 $\mathrm{mm}$, and $6 \mathrm{~mm}$ cork/burnt clay tiles on top of the roof surface. Conventional wall was constructed using brick/stone of $200 \mathrm{~mm}$ to $230 \mathrm{~mm}$ and gypsum plaster of $12 \mathrm{~mm}$ to $15 \mathrm{~mm}$ thickness on both sides of the wall [22-23].

\section{Fig.1. Photographs of buildings chosen for the field study of thermal comfort}

The survey buildings provided adaptive controls such as opening or closing of window, door and ventilator, switch on/off fan, and fan speed regulator. Very few buildings offered the use of evaporative cooling during harsh summer weather conditions. Figure 2 depicts the adaptive controls and survey environment of some of the study buildings.

\section{Fig.2. Control conditions and survey environment in the subject buildings}

Single clear glass windows allow more heat to enter the building spaces, and warmer surface temperature influences people's thermal comfort, particularly if they are sitting close to the window [23]. Window assemblies from $95 \%$ of the buildings had single clear glass of 4-8 $\mathrm{mm}$ thickness and very few $(0.5 \%)$ windows were double glazed windows. Other window glass types included single tinted glass and single clear glass with reflective coatings. During the study, a note was made of the solar exposure (exposed or unexposed building façade) to building façade and roof. A total of $27 \%$ samples were collected from roof exposed built spaces whereas remaining (73\%) samples corresponded to spaces under unexposed roof surfaces. 


\subsection{Subjects responses and sample size}

The questionnaire was developed from a previous study i.e. Dhaka et al. [24] and the same questionnaire was administered to occupants of the study buildings to record their responses. Questionnaire collected sensation and preference votes for thermal environment variables such as room temperature, relative humidity, and air velocity on a seven-point sensation scale and five-point preference scale, respectively. During the field study, the researcher rather than the occupant filled out a form. This form was used to measure environment variables, and observe the surrounding conditions of study subject. The study was conducted between 9:00 am to 6:00 pm for the period of April 11, 2011 to May 10, 2013. The subjects demonstrated an interest to be a part of this study and took approximately 10 minutes to fill up the questionnaire. Table 1 demonstrates the sensation and preference scale and their descriptions on seven and five point scale, respectively. During the study, 2859 samples were collected; of these, which $64 \%(\mathrm{~N}=1811)$ samples correspond to naturally ventilated buildings and are analysed in the following sections.

\section{Table 1. Description of scales used to measure sensations and preferences of subjects}

\subsection{Physical measurements of environment variables}

Simultaneously with the questionnaire, physical measurements of environment variables were made nearby to the respondent using high accuracy instruments. The measurements taken were at approximately $1.1 \mathrm{~m}$ height from floor level, following class-II protocol $[9,25]$. Under this protocol, thermal environmental variable $\left(T_{a}, T_{g}, V_{a}, R H\right.$, clo, met) were measured at the same time and place as the thermal questionnaire administered to the occupants. Measurements may not have been made at different heights above floor level as specified in ASHRAE (1992) and ISO (1994) standards. Table 2 demonstrates the details of sensors used to measure the indoor environment variables. During the study, we recorded the indoor air quality (concentration of carbon dioxide, $\mathrm{CO}_{2}$ ) and visual quality (lighting level, Lux) also. 


\section{Table 2. Instruments description used in the field study}

Clothing insulation of traditional clothing ensembles such as cotton sari-and-blouse, polyester sari-and-blouse, cotton salwar-kameez, polyester salwar-kameez, dhoti, baniyan and so on were considered from a field study conducted in composite climate of India [12]. Standard clothing ensembles checklist and metabolic activity checklists were used from ASHRAE fundamental [26]. Clothing insulation, activity rate, and thermal environment variables were used to determine the PMV-PPD index for the samples collected during the study.

\subsection{Data segregation}

Subject responses and physical measurements collected during the field study were compiled and then segregated as per needs for particular analysis. Statistical tool named SPSS (Statistical Package for Social Science, Statistics 21) and R program [27] was used for data analysis. For the seasonal comfort analysis, months across the year were segregated into different seasons namely, winter, moderate, and summer. A particular month was considered winter if the daily mean outdoor temperature varied between $4-25^{\circ} \mathrm{C}$ for more than or equal to 20 days of that month. A particular month was considered summer if daily mean outdoor temperature varied between $27-43^{\circ} \mathrm{C}$ for more than or equal to 20 days of that month, and the remaining months were considered as part of the moderate season [21]. Since many researchers worldwide are familiar with the field studies performed by Brager and de Dear, and Humphreys, therefore findings from these studies are compared with the results of present field study.

\section{Analysis and results}

\subsection{Variations in outdoor and indoor thermal environment}

Mean outdoor dry bulb temperature and relative humidity in the composite climate of Jaipur varied from $15-34{ }^{\circ} \mathrm{C}$ and $27-78 \%$, respectively. Minimum and maximum outdoor dry bulb temperature was $12{ }^{\circ} \mathrm{C}$ and $45^{\circ} \mathrm{C}$ during the field study. Room air temperature fluctuated 
from $14.4{ }^{\circ} \mathrm{C}$ to $39.1{ }^{\circ} \mathrm{C}$. This, large variation in outdoor dry bulb temperature affected indoor temperature conditions and thereby occupant comfort temperatures. Figure 3 depicts the monthly variation in indoor and outdoor temperatures for whole data sets. Furthermore, months were segregated into different seasons. Analysis of the outdoor climate data indicated that November to February could be considered as the winter season, April to September comprised the summer season, and the remaining two months of March and October accounted for the moderate season.

There were large variations in relative humidity $(8-96 \%)$ recorded from winter to summer period with an average humidity of $42 \%$. Due to rain, humidity was high during the summer season. In the summer, occupants kept the windows and doors open and used fans for maintaining comfort, and therefore in comparison to the winter and moderate seasons, measured air velocity was higher. Mean air velocity was observed to be $0.52 \mathrm{~m} / \mathrm{s}$ accounting for all seasons. Mean room air velocity was found to increase with an increase in mean room air temperature from the winter $\left(\mathrm{T}_{\mathrm{a}} 21.3{ }^{\circ} \mathrm{C}, \mathrm{V}_{\mathrm{a}} 0.19 \mathrm{~m} / \mathrm{s}\right)$ to moderate $\left(\mathrm{T}_{\mathrm{a}} 28.9{ }^{\circ} \mathrm{C}, \mathrm{V}_{\mathrm{a}} 0.55\right.$ $\mathrm{m} / \mathrm{s})$ to summer $\left(\mathrm{T}_{\mathrm{a}} 31.82{ }^{\circ} \mathrm{C}, \mathrm{V}_{\mathrm{a}} 0.76 \mathrm{~m} / \mathrm{s}\right)$ study periods. This increase in air velocity indicated that when subjects like to experience more air velocity as the ambient conditions become warmer. Table 3 shows the seasonal variations in indoor environment variables and outdoor temperature.

\section{Fig.3. Monthly variation in indoor and outdoor temperatures}

\section{Table 3. Summary of seasonal variations in environment variables}

Clothing insulation influences the heat balance between the person and surrounding environment, and this in turn affects the subject's thermal sensation at a particular temperature. Clothing insulation for traditional clothing ensembles such as cotton sari-andblouse 0.54 clo, polyester sari-and-blouse 0.61 clo, cotton salwar-kameez 0.44 clo, polyester salwar-kameez 0.53 clo were considered. The minimum clothing insulation was found to be 
0.19 clo whereas it was observed to be 0.45 clo during summer and 0.63 clo during winter period of the study. The average clothing of the study group observed to be 0.52 clo considering all data sets.

The mean activity of the subjects was observed to be $1.05 \mathrm{met}\left(1 \mathrm{met}=58.2 \mathrm{~W} / \mathrm{m}^{2}\right)$ and it indicated light/office activity of study subjects. The visual quality (lighting intensity) of indoor environment was satisfactory and average lighting level observed was 223 lux. Indoor air quality $\left(\mathrm{CO}_{2}\right.$ concentration) was recorded using air quality analyser (Testo 435-2). Mean $\mathrm{CO}_{2}$ concentration observed was $560 \mathrm{ppm}$, which indicated good indoor air quality [28].

\subsubsection{Variation in indoor and outdoor temperatures}

Measurements revealed a strong correlation $(r=0.93)$ between room temperature $\left(T_{a}\right)$ and outdoor temperature $\left(\mathrm{T}_{\mathrm{o}}\right)$ as indicated by equation 1 , lending support to the idea that outdoor dry bulb temperature will likely affect the thermal sensation (and neutral temperature) of an individual or group of subjects.

$\mathrm{T}_{\mathrm{a}}=0.8 \mathrm{~T}_{\mathrm{o}}+4.07$

\subsection{Sample size and physical characteristic of subjects}

During the study, an average of 150 samples/month was collected. Figure 4 shows that maximum subject responses $(16 \%)$ were collected in February whereas the minimum were collected in December (2\%). The subject responses of $33.2 \%, 18.8 \%$ and $48 \%(\mathrm{~N}=870)$ were collected during winter, moderate (March and October) and summer seasons, respectively. About $64 \%$ of the respondents were male and $66.7 \%(\mathrm{~N}=1227)$ responses occurred in the second half of the day, corresponding to 12:01 pm to 6:00 pm.

\section{Fig.4. Monthly distribution of subject responses}

Table 4 illustrates the descriptive summary of the physical characteristics of the subjects such as height, weight, body surface area and age. The mean age of the occupants was 
approximately 24 years, which indicated participation of young subjects. The mean height and weight and body surface area observed were $1.67 \mathrm{~m}$ and $60.25 \mathrm{~kg}$ and $1.67 \mathrm{~m}^{2}$, respectively.

\section{Table 4. Summary of physical characteristics of respondents}

\subsection{Thermal sensation}

Thermo-physical responses using ASHRAE's seven-point Thermal Sensation Scale (TSS) were categorized into cold '-3', cool '-2', slightly cool '-1', neutral '0', slightly warm ' 1 ', warm ' 2 ', and hot ' 3 '. The traditional assumption is that people voting within the central three categories of the thermal sensation $(-1,0,+1)$ are deemed comfortable. Table 5 shows the summary of sensations and preferences of subjects for different seasons.

The mean thermal sensation of the subjects for all the seasons combined was 0.13 , which represents a sensation slightly warmer than neutral. During winter, the subject's mean thermal sensation was -0.84 , and during summer, it was 0.73 . Figure 5 depicts the percentage sensation votes collected during the present field study of thermal comfort. A total of $76.1 \%$ subjects felt thermally comfortable (i.e. votes found within three central categories of thermal sensation) at prevailing indoor thermal conditions. A total of $15.1 \%$ subjects were thermally dissatisfied due to warm thermal conditions (sensation higher than +1 ) and $8.8 \%$ subjects felt thermal dissatisfaction due to coolness (sensation less than -1). During the study, about one third of the subjects $(27.4 \%)$ did not complain of warm or cool indoor thermal environment; these subjects voted for neutral thermal sensation.

Table 5. Summary of sensation and preference variables at room conditions

\section{Fig.5. Thermal sensation votes on ASHRAE's seven-point scale}

Figure 6 describes the distribution of subject's sensation votes over room temperature through box plot representation. A box represents $50 \%$ of the total subject responses whereas upper and lower whisker indicates maximum and minimum room temperature for particular sensation. Bold horizontal line within the box represents median of the subject's votes. A 
lower whisker height, for example in case of 'very cold' sensation (-3), indicates that responses in the lower quartile are distributed within smaller range of room temperature. Whereas, longer whisker length, for example lower quartile at neutral sensation (' 0 ' sensation), indicates a wide spread of subject responses.

\section{Fig.6. Distribution of thermal sensation votes over room temperatures}

Further to analyse the effect of temperature on thermal sensation; room temperature was binned by $2{ }^{\circ} \mathrm{C}$ (temperature range between $14{ }^{\circ} \mathrm{C}$ and $40{ }^{\circ} \mathrm{C}$ ) for thermal sensation votes ranges from -3 (cold) to +3 (hot). It shows that occupants start feeling coolness for temperature bin $14-16^{\circ} \mathrm{C}$ and warmness until temperature bin of $36-38^{\circ} \mathrm{C}$. Maximum $88 \%$ subjects were found thermally satisfied for temperature bin $24-26^{\circ} \mathrm{C}$ and more than $80 \%$ of subjects were thermally comfortable between temperatures bin of $22-24^{\circ} \mathrm{C}$ and $30-32^{\circ} \mathrm{C}$. The study observed higher comfort (votes found within central category of $+/-1$ ) bandwidth of 10 ${ }^{\circ} \mathrm{C}$ in naturally ventilated buildings of composite climate. The subjects perceived warmness (either warm or hot) and coolness (either cool or cold) at higher and lower room temperatures.

\subsubsection{Thermal neutrality}

Thermal neutrality refers to specific room air temperature corresponding to mean thermal sensation vote of 'zero' on thermal sensation scale. Linear regression was performed for all data-all seasons between subject's thermal sensation votes and corresponding room air temperatures to determine the neutral temperature of the group as depicted in Figure 7. Equation 2 shows the relationship between thermal sensation and room temperature. Neutral temperature of the group was found to be $27.21^{\circ} \mathrm{C}(\mathrm{R}=0.711)$ considering all subjects response across all seasons. The study observed a significant $(\mathrm{p}<0.05)$ difference in the thermal sensation of male and female subjects (regressions were done separately for each group as shown in equations 3 and equation 4). Present study observed higher clothing for female subjects $(0.57 \mathrm{clo})$ as compared to the male subjects $(0.48 \mathrm{clo})$. Further analysis 
revealed presence of lesser air velocity in female occupied spaces $(0.4 \mathrm{~m} / \mathrm{s})$ than the male occupied spaces $(0.6 \mathrm{~m} / \mathrm{s})$. Subjects can use clothing adjustment to adopt wide range of temperatures; this also suggests that there may be non-behavioural ways in which people adopted to the environment. Body Surface Area (BSA) also affects overall heat balance between occupant and surrounding environment. Females have less BSA and hence have a lower neutral temperature as compared to males. As a result, neutral temperature of female subjects $\left(26.98{ }^{\circ} \mathrm{C}\right)$ was $0.42^{\circ} \mathrm{C}$ lower than that of male subjects $\left(27.40{ }^{\circ} \mathrm{C}\right)$.

Thermal Sensation $\left(\mathrm{TS}_{\mathrm{C}}\right)=0.169 \mathrm{~T}_{\mathrm{a}}-4.598$

$\mathrm{TS}_{\text {Female }}=0.174 \mathrm{~T}_{\mathrm{a}}-4.696$

$\mathrm{TS}_{\text {Male }}=0.168 \mathrm{~T}_{\mathrm{a}}-4.604$

Fig.7. Regression plot between thermal sensation votes and room temperatures

\subsubsection{Effect of seasonal variations on thermal neutrality}

This study illustrates that indoor and outdoor temperatures have a strong correlation to each other; therefore, thermal neutrality was determined separately for different seasons. The mean thermal sensation $\left(\mathrm{TS}_{\mathrm{Mean}}\right)$ of subjects increased as outdoor temperatures increased from winter $\left(\mathrm{TS}_{\text {Mean }}-0.84, \mathrm{~T}_{\mathrm{o}} 22.32{ }^{\circ} \mathrm{C}\right)$ to moderate $\left(\mathrm{TS}_{\text {Mean }} 0.36, \mathrm{~T}_{\mathrm{o}} 31.28{ }^{\circ} \mathrm{C}\right)$ to summer $\left(\mathrm{TS}_{\text {Mean }}\right.$ $0.73, \mathrm{~T}_{\mathrm{o}} 34.03{ }^{\circ} \mathrm{C}$ ) periods of the study. Neutral temperatures for winter, moderate and summer seasons determined through linear regression were $25.64{ }^{\circ} \mathrm{C}, 27.0{ }^{\circ} \mathrm{C}$, and $29.4{ }^{\circ} \mathrm{C}$, respectively. Table 6 shows the statistical correlations and relationship between thermal sensation and room air temperature along with thermal neutrality for different seasons.

\section{Table 6. Summary of seasonal variations in thermal neutrality}

During the summer season, outdoor temperature varied from $25-45^{\circ} \mathrm{C}$ whereas room temperature fluctuated from $26{ }^{\circ} \mathrm{C}$ to $39{ }^{\circ} \mathrm{C}$, and indoor comfort temperatures were higher as well. Neutral and comfort temperatures (sensation votes lie within +/-1) from the present study were found higher than the national/international comfort standards. Equation 5 shows 
the relationship between thermal sensation and room temperature for naturally ventilated buildings during summer season. Indraganti [15] also found similar results for summer comfort study.

$\mathrm{TS}_{\mathrm{S}}=0.299 \mathrm{~T}_{\mathrm{a}}-8.788$

\subsection{Sensation and preference for humidity}

Humidity sensation was asked on a seven-point scale that ranged from ' -3 ' to ' +3 ', described as very dry '-3', moderately dry '-2', slightly dry '-1', acceptable ' 0 ', slightly humid '1', moderately humid ' 2 ' and very humid ' 3 '. Relative humidity during the study was found between $8 \%$ and $96 \%$. Mean humidity sensation for all data sets was +0.11 at relative humidity of $42 \%$. Maximum humidity observed was during the summer season due to rain, and was least in the moderate season. Figure 8 describes the variations in humidity sensation votes over relative humidity. Mean humidity for slightly humid, moderately humid and very humid sensations was $52 \%, 52.4 \%$, and $63 \%$ respectively; whereas, mean humidity for slightly dry, moderately dry and very dry sensations was $30 \%, 28 \%$, and $27 \%$, respectively. Further analysis carried out on humidity sensation indicated that more than $54 \%$ of the subjects accepted the humidity between $33 \%$ and $38 \%$.

\section{Fig.8. Variations in humidity sensation votes over relative humidity}

Linear regression between the humidity sensation votes and the corresponding relative humidity was performed to determine the ideal humidity level $\left(\mathrm{HS}_{\text {ideal }}\right)$ for the study group. As per the method used for determining neutral temperature (i.e., solving the regression for a mean sensation of zero), 'ideal humidity' was found to be $36 \%$. Equation 6 indicates the relationship between ideal humidity and relative humidity. A large proportion of subjects perceived conditions to be 'slightly humid' and 'moderately humid' for a wide range of RH conditions (10\% to $90 \%)$.

Ideal humidity, $\mathrm{HS}_{\text {Ideal }}=0.03 \mathrm{RH}-1.087$ 
Humidity preferences were asked on a five-point scale described as very dry '-2', a bit dry '1', 'acceptable or no change' '0', a bit humid ' 1 ' and very humid ' 2 '. Figure 9 shows that 75

$\%$ of the subjects preferred to reside at prevailing humidity conditions. Few subjects preferred to reside at very dry (23\% subjects accepted very dry conditions) and more humid conditions either moderately humid (13\%) or very humid (less than $5 \%$ ). This may be due to their nativity of dry and humid climatic conditions. Maximum $75 \%$ subjects preferred to accept (no change) the prevailing humidity conditions. As expected, occupants who voted for more humid sensation scale simultaneously voted that they preferred to be 'a bit dry', and viceversa.

Fig.9. Tabulated summary of humidity preference votes on humidity sensation scale Present study observed higher variations in humidity preferences throughout the sensation scale. Few subjects preferred to reside at 'very humid' and 'very dry' conditions.

\subsection{Sensation and preference for air velocity}

Use of PMV model as given in ASHRAE Standard 55 (2010) limits the air velocity below 0.2 $\mathrm{m} / \mathrm{s}$ whereas graphical elevated air velocity method and Standard Effective Temperature (SET) method allows use of elevated air velocity for comfort improvement as mentioned in ASHRAE 55 (2010). It reveals that increased air velocity can be used to improve the comfort level but it is limited to maximum of $0.8 \mathrm{~m} / \mathrm{s}$ without local controls of air velocity.

The subjects from study buildings were asked to rate the sensation of air velocity on a sevenpoint scale described as 'very low' '-3', 'moderately low' '-2', 'slightly low' '-1', 'just right or ideal' ' 0 ', 'slightly high' ' 1 ', 'moderately high' '2' and 'very high' '3'. Mean air velocity across all seasons was approximately $0.53 \mathrm{~m} / \mathrm{s}$, whereas maximum and minimum air velocity was observed to be $1.71 \mathrm{~m} / \mathrm{s}$ and $0 \mathrm{~m} / \mathrm{s}$, respectively. Mean air velocity increased as the seasons got warmer, and was $0.19 \mathrm{~m} / \mathrm{s}$ (winter), $0.55 \mathrm{~m} / \mathrm{s}$ (moderate) and $0.76 \mathrm{~m} / \mathrm{s}$ (summer). Using the scale described above, mean sensation of air velocity in the different seasons was - 
0.20 (winter), -0.14 (moderate), and -0.04 (summer). It is interesting that although air velocity was higher in the summer compared to the moderate season, perceptions of air velocity in summer actually decreases. This might suggest that people were not necessarily voting based on what the air velocity was, but may have been perceiving it relative to what would have been desirable for their comfort state. In other words, even though the summer air velocity was higher, it was less than what they would have desired, and therefore they voted that was slightly low relative to what was acceptable.

Ideal (just right) air velocity was perceived by $48 \%(\mathrm{~N}=862)$ subjects whereas $24 \%$ voted towards higher air velocity and $28 \%$ perceived low air velocity. Linear regression was performed between air velocity sensation votes and air velocity to determine ideal air velocity of the subjects. Ideal air velocity was found to be $0.44 \mathrm{~m} / \mathrm{s}$. Equation 7 illustrates the relationship ( $\mathrm{r}=0.3$ ) between ideal air velocity and air velocity present in the indoor spaces during the field survey.

Ideal air velocity, $\mathrm{VS}_{\text {Ideal }}=1.017 \mathrm{~V}_{\mathrm{a}}-0.452$

Figure 10 exhibits the distribution of air velocity sensation votes over room air velocity. The study reveals large variations in the air velocity sensations across the sensation labels. This is due to large variation in combinations of indoor temperature, relative humidity and air velocity that were found during the study.

Fig.10. Box plot between air velocity sensation votes and room air velocity

Figure 11 shows the stacked bar chart for preference votes across air velocity sensation labels. It demonstrates that large variation in room air velocity was found from an individual's room environment and many of the subjects expected to have higher air velocity than prevailing air velocity. Maximum $60.5 \%$ of subjects preferred to reside at prevailing conditions.

Fig.11. Tabular summary between air velocity sensation and air velocity preference 
The study observed that at least $20 \%$ of subjects preferred 'no change' to air velocity across all the sensation labels and at the same time at least $25 \%$ of subjects preferred to have slightly high air velocity. It is interesting that less percentage of subjects observed whose preferences were towards less air velocity and instead of this, most of the subjects preferred slight high air movement for their comfort conditions.

\subsection{Thermal neutrality and outdoor temperature}

The objective of the study is to derive the relationship between comfort temperature and outdoor temperature. To accomplish this, among all responses collected on seven-point thermal sensation scale, neutral sensation votes were chosen and then a relationship was derived with the outdoor dry bulb temperature. The linear regression analysis carried out between neutral sensation votes and outdoor dry bulb temperature demonstrated a strong correlation $(\mathrm{r}=0.87)$, as illustrated by equation 8 . This relationship revealed that outdoor temperature influences the state of comfort. Since all the votes corresponded to neutral sensation only, thereby this temperature is assumed as comfort temperature in the present study.

Previous field studies of thermal comfort proposed relationships between comfort temperature and outdoor dry bulb temperature for naturally ventilated buildings located in different climates. The comfort temperature equation proposed by Humphreys is a result of field studies of thermal comfort mostly conducted in cold climatic locations [7]. de Dear and Brager [8] collected about 21,000 sets of raw thermal comfort data from 160 buildings covering most of thermal comfort field research groups around the world. Mainly, thermal comfort data was collected from buildings located in moderate and cold climate; very few data sets were collected from hot \& dry and composite climatic locations. Therefore, this study attempts to compare its findings with the comfort temperature relationship derived by de Dear and Brager, and Humphreys as represented in equation 9 and equation 10 
respectively. Figure 12 demonstrates the comparison of the relationships between comfort temperature and outdoor temperature found by those studies, and 'present study'. Horizontal dotted lines on Y-axis (comfort temperature axis) of Figure 12 indicate the minimum (16.7 $\left.{ }^{\circ} \mathrm{C}\right)$ and maximum $\left(34.8{ }^{\circ} \mathrm{C}\right)$ comfort temperature. Comfort temperature denoted by blue circles and green squares in Figure 12 was calculated using the outdoor temperatures (raw data) corresponding to the neutral sensation votes of the present field data. Scatters were observed at the ends of lines proposed by de Dear and Brager and Humphreys due to less number of survey samples at lower and upper end temperatures.

Comfort temperature, $\mathrm{T}_{\text {comf }}=0.75 \mathrm{~T}_{\mathrm{o}}+5.37$

Comfort temperature, de Dear $\mathrm{T}_{\text {comf }}=0.31 \mathrm{~T}_{\mathrm{o}}+17.8$

Comfort temperature, Humphreys $\mathrm{T}_{\text {comf }}=0.534 \mathrm{~T}_{\mathrm{o}}+12.9$

Where, $\mathrm{T}_{\text {comf }}$ - comfort temperature, $\mathrm{T}_{\mathrm{o}}$ - mean outdoor dry bulb temperature

Fig.12. Comparison of comfort temperature for present study and previous studies of thermal comfort

The study observed that slope of present study line i.e. 'present study' is steeper as compared to the field studies performed by de Dear and Brager, and Humphreys. This indicated that subjects from the study climate (very hot during summer and cold in winter season) are more adaptive to the thermal environment. The subjects voted to be thermally comfortable for a wide range of indoor air temperatures $\left(16.7^{\circ} \mathrm{C}\right.$ to $\left.34.8^{\circ} \mathrm{C}\right)$ whereas de Dear and Brager equation revealed that subjects are comfortable between $21.5^{\circ} \mathrm{C}$ and $30.5{ }^{\circ} \mathrm{C}$ (calculated from Eq. 9). The comfort temperature revealed from Humphreys's relationship was found inbetween the study conducted by de Dear and Brager and the present study. It resulted that occupants from the present study feel thermally comfortable at higher indoor temperature ranges as compared to the studies performed by Humphreys and de Dear and Brager. This is 
due to thermal adaptation of particular thermal environment conditions in Indian composite climate.

The one strong reason for showing higher thermal adaptation of study subject is psychological adaptation (one's thermal experiences and expectations) that refers to an altered perception or response due to exposure of particular thermal environment over a long period. Mostly, the study subjects are the native population (composite climate) and experience large variations in outdoor and indoor thermal environment on regular basis. The role of behavioral adaptation (adaptive opportunity and behavioral adjustment) is also the key factor for adaptation. All the naturally ventilated buildings provided adequate controls $\&$ adjustments to overcome discomfort during harsh summer and winter conditions. Therefore, subjects from present study felt thermally comfortable over a wide range of temperate.

\subsection{Thermal acceptability}

Thermal Acceptability (TA) is expressed as thermal satisfaction with the indoor thermal environment and used to determine the range of acceptable temperature. A comfort zone can correspond to either $80 \%$ acceptability or $90 \%$ acceptability (i.e., a narrower acceptable temperature range where only $10 \%$ of the people are dissatisfied). ASHRAE Standard 55 defined comfort zone in terms of ranges of operative temperature, with assumptions about the other personal and environmental variables that affect temperature. The adaptive comfort zone was developed by starting with the comfort temperature described by equation (9). In the present study, upper and lower thermally acceptability limits around the comfort were determined starting with Fanger's PMV-PPD relationship, where 80\% and 90\% satisfaction is based on an average thermal sensation of +0.85 and +0.5 , respectively, which translated to a range of operative temperature of +3.5 and $+2.5[8]$.

Equation 11-14 shows the upper and lower thermal acceptability limits for $90 \%$ and $80 \%$ acceptability. Figure 13 depicts the thermal acceptability for the present study and also for the 
ASHRAE comfort zone, using comfort temperature equations suggested by de Dear and Brager [8].

Upper $90 \%$ thermal acceptability limit: $\mathrm{T}_{\mathrm{AU}, 90 \%}=0.75 \mathrm{~T}_{\mathrm{o}}+8.87$

Lower $90 \%$ thermal acceptability limit: $\mathrm{T}_{\mathrm{AL}, 90 \%}=0.75 \mathrm{~T}_{\mathrm{o}}+1.87$

Upper $80 \%$ thermal acceptability limit: $\mathrm{T}_{\mathrm{AU}, 80 \%}=0.75 \mathrm{~T}_{\mathrm{O}}+7.87$

Lower $80 \%$ thermal acceptability limit: $\mathrm{T}_{\mathrm{AL}, 80 \%}=0.75 \mathrm{~T}_{\mathrm{o}}+2.87$

Where, $\mathrm{T}_{\mathrm{AU}}$ and $\mathrm{T}_{\mathrm{AL}}$ represent upper and lower thermal acceptability limits.

Fig.13. 90\% and $80 \%$ acceptability for present study (a) acceptability for naturally ventilated buildings as per ASHRAE Standard 55 (b)

For ASHRAE comfort zone, outdoor temperature is limited between 10 and $33.5^{\circ} \mathrm{C}$ as presented in Figure 13 (b). It revealed that ASHRAE neglected the comfort temperature beyond the specified limit of outdoor temperature. Comparison demonstrated the difference in slope, which indicated the effect of adaptation.

\subsection{Comparison of comfort models}

The study calculated the thermal comfort indices such as PMV and PPD using thermal environmental variables collected during the study and then compared the PMV index with the thermal sensation votes. PMV values at +3 and -3 represents $100 \%$ thermal dissatisfaction. Mean PMV was found to be 0.3 and the corresponding PPD was $53.22 \%$. Heat balance model of thermal comfort prescribed the comfort limit within PMV bandwidth of \pm 0.5 whereas adaptive model of thermal comfort defined comfort within central three categories $(+/-, 1)$ of thermal sensation scale.

Figure 14 demonstrates the relationship between mean PMV and mean Thermal Sensation Vote (TSV) for the corresponding room air temperature, and equations 15 and 16 describe these relationships. When subjects voted towards warm sensation (TSV >0), PMV was found to be higher, and vice-versa, which indicates that PMV overestimated thermal sensation in 
warm conditions, and underestimated for cooler sensations. Similar results were reported by previous research carried out for different buildings as well as different climates, as reported by de Dear et al. [8, 17].

$\mathrm{PMV}=0.15 \mathrm{~T}_{\mathrm{a}}+4.14$

$\mathrm{TSV}=0.32 \mathrm{~T}_{\mathrm{a}}-8.67$

\section{Fig.14. Comparison between thermal sensation votes and PMV index}

Adaptive comfort model indicated thermal satisfaction at higher room temperature during summer conditions and at lower room temperatures during winter. As per the comfort convention (central three categories of sensation scale), subject felt thermally comfortable within wide range of room air temperatures, which revealed higher adaptation of study subjects. This is possibly due to exposure of higher outdoor dry bulb temperatures, large variations in indoor temperatures and social and cultural differences.

\subsection{Conclusion}

This paper presents results of a field study of thermal comfort conducted in thirty naturally ventilated buildings, including residential and office buildings, from composite climatic zone of India. The questionnaire was administered to building occupants to record sensations and preferences for room temperature, relative humidity and air velocity. Simultaneously, indoor environmental variables and surrounding conditions of the subject were recorded considering class-II protocol of field measurement. The study collected a total of 1811 subject responses from January to December for three consecutive years. Due to large variation in weather conditions in different parts of any year, the collected data was segregated into three categories, namely: summer months, winter months and moderate months. Analysis of neutral temperature was carried out for each of the three categories separately to observe change in comfort temperature with respect to season.

Key conclusions of the study are:

- Average body surface area of the subject was observed less as compared to the standard body surface area suggested by thermal comfort standards. 
- The study observed a strong correlation between indoor and outdoor temperatures. It indicated that indoor thermal environment in naturally ventilated buildings is largely affected by varying outdoor conditions. In line to this, occupant encountered variable environment conditions in the study buildings throughout the day and during discomfort they used different controls for achieving thermal comfort state.

- The neutral temperature of the group was found to be $27.2{ }^{\circ} \mathrm{C}$ (considering all data-all seasons). Neutral temperature for winter, moderate and summer season was found to be $25.6{ }^{\circ} \mathrm{C}, 27{ }^{\circ} \mathrm{C}$, and $29.4{ }^{\circ} \mathrm{C}$, respectively.

- The study concludes that seasonal variations affected the thermal sensation of subjects and thereby the neutral temperature. During summer, subject felt neutral sensation at higher room temperatures and vice-versa.

- Availability and accessibility of controls can provide thermally comfortable indoor conditions to building occupants during harsh summer and winter conditions. The study observed that most of the survey spaces provided operable windows and fans to overcome discomfort.

Thereby, thermal acceptability at $80 \%$ and $90 \%$ was found to be higher as compared to ASHRAE's thermal acceptability limits in their adaptive comfort zone model. The study revealed that subjects from warm climatic conditions are more adaptive to the climatic variations and feel thermally comfortable at higher temperatures as compared to previous field studies conducted by Humphreys and de Dear and Brager.

- The study observed higher variations in air movement sensation. Some subjects perceived ideal air velocity at higher air speed. The study also observed that during higher room temperature, subjects preferred higher air velocity.

- The study observed faster adaption to the indoor thermal environment. The slope of the regression line was observed higher than the previous referred studies. 
- The study concludes that the PMV model overestimates and underestimates thermal sensation of subjects during warm and cool conditions, respectively.

Present study can play important role in designing naturally ventilated buildings located in warm, and hot \& dry conditions. It can also serve as a guide to building designers, architects, and engineers to create comfortable indoor thermal environment for a wide range of indoor temperature conditions. More similar studies should be conducted at diverse climatic locations and attempts should also be made to establish correlation between climatic conditions of any location and comfort temperature.

\section{Acknowledgement}

This work was partially supported by Joint Clean Energy Research Development Center (JCERDC) for buildings called Center for Building Energy Research, and Development (CBERD) funded by the Indian Ministry of Science \& Technology, and U.S. Department of Energy and administered by Indo-US Science and Technology Forum in India.

\section{Nomenclature}

\begin{tabular}{llll}
\hline PMV & Predicted Mean Vote & $\mathrm{T}_{\mathrm{o}}$ & Outdoor dry bulb temperature $\left({ }^{\circ} \mathrm{C}\right)$ \\
PPD & Percentage Predicted & $\mathrm{T}_{\mathrm{g}}$ & Globe temperature $\left({ }^{\circ} \mathrm{C}\right)$ \\
& Dissatisfied & & \\
TSV & Thermal Sensation Vote & $\mathrm{T}_{\mathrm{a}}$ & Room air temperature $\left({ }^{\circ} \mathrm{C}\right)$ \\
TSS & Thermal sensation scale & $\mathrm{T}_{\mathrm{c}}$ & Comfort temperature $\left({ }^{\circ} \mathrm{C}\right)$ \\
TP & Thermal preference & $\mathrm{T}_{\mathrm{n}}$ & Neutral temperature $\left({ }^{\circ} \mathrm{C}\right)$ \\
$\mathrm{HP}$ & Humidity preference & $\mathrm{V}_{\mathrm{a}}$ & Air velocity $(\mathrm{m} / \mathrm{s})$ \\
$\mathrm{HS}$ & Humidity sensation & $\mathrm{r}$ & Correlation coefficient \\
VaP & Air velocity preference & $\mathrm{SD}$ & Standard deviation \\
VisualS & Visual sensation & $\mathrm{Range}$ & Maximum-Minimum \\
VisualP & Visual preference & $\mathrm{CO}$ & Carbon dioxide concentration $(\mathrm{ppm})$ \\
SHGC & Solar Heat Gain Coefficient & $\mathrm{N}$ & No of survey sample \\
$\mathrm{R}^{2}$ & Coefficient of determination & $\mathrm{H}$ & Height, m \\
clo & Clothing insulation & $\mathrm{W}$ & Weight, kg \\
\hline
\end{tabular}




\begin{tabular}{lll}
\hline & 1 clo $=0.155 \mathrm{~m}^{2} \mathrm{~K} / \mathrm{W}$ & \\
met & Metabolic rate & \\
& $1 \mathrm{met}=58.2 \mathrm{~W} / \mathrm{m}^{2}$ & \\
VaS & Air velocity sensation & Lux $\quad$ Lighting intensity (Lux) \\
\hline
\end{tabular}

\section{References}

1. de Dear R, Brager G. Developing an Adaptive Model of Thermal Comfort and Preference. ASHRAE Transactions 1998;104(1):145-167.

2. ANSI/ASHRAE 55-2010. Thermal environmental conditions for human occupancy; 2010. ANSI/ASHRAE 55-2010.

3. ISO7730. Ergonomics of the thermal environment-analytical determination and interpretation of thermal comfort using calculation of the PMV and PPD indices and local thermal comfort criteria. 3rd edition. Geneva; 2006.

4. Fanger PO. Thermal comfort, analysis and applications in environmental engineering. New York: McGraw-Hill; 1972.

5. Auliciems A. Towards a Psycho-Physiological Model of thermal perception. Int. J. Biometeor 1981;25(2):109-122.

6. Humphreys MA. Outdoor temperatures and comfort indoors. Building Research and Practices (J.CIB) 1978;6(2):92-105.

7. Brager GS, de Dear RJ. Thermal adaptation in the built environment: a literature review. Energy and Buildings 1998;27:83-96.

8. de Dear RJ and Brager GS. The Adaptive Model of Thermal Comfort and Energy Conservation in the Built Environment, International Journal of Biometeorology 2001; 45(2):100-108.

9. Feriadi H, Wong NH. Thermal comfort for naturally ventilated house in Indonesia. Energy and Buildings 2004;36:614-626. 
10. Nicol JF, Roaf S. Pioneering new indoor temperature standards: the Pakistan project. Energy Build 1996;23:169-74.

11. Sharma MR, Ali S. Tropical Summer Index - a Study of Thermal Comfort of Indian Subjects, Building and Environment 1986;21(1):11-24.

12. Indraganti M. Using the adaptive model of thermal comfort for obtaining indoor neutral temperature: Findings from a field study in Hyderabad, India. Building and Environment 2010;45:519-536.

13. Mishra AK, Ramgopal M. Thermal comfort in undergraduate laboratories-A field study in Kharagpur, India, Building and Environment 71;223-232.

14. Singh MK, Mahapatra S, Atreya SK. Adaptive thermal comfort model for different climatic zones of North-East India. Applied Energy 2011;1-10.

15. Indraganti M. Field investigation of comfort temperature in Indian office buildings: A case of Chennai and Hyderabad. Building and Environment2013; 65:195-214.

16. Zhang Y, Wang J, Chen H, Meng Q, Zhao R. Thermal adaptation in built environment - a literature review, discussion and primary exploration. Proceedings of Conference: Adapting to Change: New Thinking on Comfort Cumberland Lodge, Windsor, UK, 9-11 April 2010.

17. Yao R, Li B, Liu J. A theoretical adaptive model of thermal comfort - Adaptive Predicted Mean Vote (aPMV). Building and Environment 2009;44:2089-2096.

18. Raja A, Nicol F, McCartney KJ, Humphreys MA. Thermal comfort: use of controls in naturally ventilated buildings. Energy and Buildings 2001;33:235-244.

19. Nicol F, Humphreys MA. Adaptive thermal comfort and sustainable thermal standards for buildings. Energy and Buildings 2002;34:563-572.

20. USAID INDIA ECO-III. Energy Conservation Building Code - User Guide. Bureau of Energy Efficiency, New Delhi, 2009. 
21. Bansal NK, Minke G. Climatic Zones and Rural Housing in India. German-Indian Cooperation in Scientific Research and Technological Development, 1995. ISBN: 9783893361625.

22. Kumar A, Suman BM. Experimental evaluation of insulation materials for walls and roofs and their impact on indoor thermal comfort under composite climate. Building and Environment 2013; 59:635-643.

23. Dhaka S, Mathur J, Garg V. 2012. Combined effect of energy efficiency measures and thermal adaptation on air-conditioned building in warm climatic conditions of India. Energy and Buildings 2012;55:351-360.

24. Dhaka S, Mathur J, Wagner A, Agrawal GD, Garg V. Evaluation of thermal environmental conditions and thermal perception at naturally ventilated hostels of undergraduate students in composite climate. Building and Environment 2013;66:42-53.

25. Gossauer E, Wagner A. Post-occupancy Evaluation and Thermal Comfort: State of the Art and New Approaches. Advances in Building Energy Research 2007;1:151-175.

26. ASHRAE handbook of fundamentals. Chapter 9: Thermal Comfort. American Society of Heating Refrigeration and Air-Conditioning Engineers Inc, 2005.

27. R: a language and environment for statistical computing. Vienna, Austria: R Development Core Team, ISBN 3-900051-07-0; 2008. http://www.R-project.org; 2008.

28. ANSI/ ASHRAE Standard 62.1-2007. User's manual-ventilation for acceptable indoor air quality. Atlanta. 
Table 1. Sensations and preferences scale for temperature, humidity and air velocity

\begin{tabular}{l|lll|lll}
\hline \multirow{2}{*}{ Scale } & \multicolumn{3}{|l|}{ Seven-point sensation scale } & \multicolumn{3}{l}{ Five-point preference scale } \\
\cline { 2 - 7 } & Temperature & Humidity & Air velocity & Temperature & Humidity & Air velocity \\
\hline 3 & Hot & Very humid & Very high & - & & \\
\hline 2 & Warm & Moderately & Moderately & Much & Very & Moderately \\
& & humid & high & warmer & humid & moving \\
\hline 1 & Slightly & Slightly & Slightly & A bit & A bit & Slightly \\
& warm & humid & high & warmer & humid & moving \\
\hline 0 & Neutral & Acceptable & Just right & No change & No change & No Change \\
\hline-1 & Slightly & Slightly & Slightly & A bit & A bit & Slightly \\
& cool & dry & low & cooler & dry & low \\
\hline-2 & Cool & Moderately & Moderately & Much & Very & Moderately \\
& & dry & low & cooler & dry & low \\
\hline-3 & Cold & Very dry & Very low & - & - & - \\
\hline
\end{tabular}

Table 2. Description of instrument used in the field study

\begin{tabular}{|c|c|c|c|c|c|}
\hline S No. & Parameter & Instrument & Make & Range & Accuracy \\
\hline \multirow[t]{2}{*}{1} & Outdoor & Weather & Virtual & -40 to & $\pm 0.5^{\circ} \mathrm{C}\left(5-40{ }^{\circ} \mathrm{C}\right)$ \\
\hline & temperature & station & instrumentation & $123.8^{\circ} \mathrm{C}$ & \\
\hline 2 & Air temperature & $480 \mathrm{VAC}$ & Testo & -20 to $70{ }^{\circ} \mathrm{C}$ & $\pm 0.5^{\circ} \mathrm{C}$ \\
\hline \multirow[t]{4}{*}{3} & Globe & $480 \mathrm{VAC}$ & Testo & 0 to $120{ }^{\circ} \mathrm{C}$ & $\pm 0.5^{\circ} \mathrm{C}$ \\
\hline & temperature & & & & \\
\hline & (Diameter 150 & & & & \\
\hline & $\mathrm{mm})$ & & & & \\
\hline \multirow[t]{2}{*}{4} & Relative & $480 \mathrm{VAC}$ & Testo & 0 to $100 \%$ & $\pm(1.0 \% \mathrm{RH}+0.7$ \\
\hline & humidity (RH) & & & & $\%$ reading) \\
\hline \multirow[t]{2}{*}{6} & Air velocity & $480 \mathrm{VAC}$ & Testo & 0 to $5 \mathrm{~m} / \mathrm{s}$ & $\pm(0.03 \mathrm{~m} / \mathrm{s}+4$ of \\
\hline & & & & & reading) \\
\hline \multirow[t]{2}{*}{7} & $\mathrm{CO}_{2}$ & $435-2$ & Testo & 0 to 10000 & $\pm\left(50 \mathrm{ppm} \mathrm{CO} \mathrm{CO}_{2}+\right.$ \\
\hline & & & & ppm & $2 \%$ of reading) \\
\hline \multirow[t]{2}{*}{8} & Lighting level & LX-103 & Lutron & 0 to 50000 & $\pm 4 \%$ of 10 digit \\
\hline & & & & $\operatorname{lux}$ & \\
\hline
\end{tabular}


Table 3. Summary of seasonal variations in environment variables

\begin{tabular}{lllllllllll}
\hline $\mathrm{N}=1811$ & & $\mathrm{~T}_{\mathrm{o}}$ & $\mathrm{T}_{\mathrm{a}}$ & $\mathrm{T}_{\mathrm{g}}$ & $\mathrm{RH}$ & $\mathrm{V}_{\mathrm{a}}$ & \multicolumn{3}{c}{ Activity } & Clothing \\
& & $\left({ }^{\circ} \mathrm{C}\right)$ & $\left({ }^{\circ} \mathrm{C}\right)$ & $\left({ }^{\circ} \mathrm{C}\right)$ & $(\%)$ & $(\mathrm{m} / \mathrm{s})$ & $(\mathrm{met})$ & $(\mathrm{clo})$ & $(\mathrm{Lux})$ & $(\mathrm{ppm})$ \\
\hline Winter & Mean & 22.32 & 21.32 & 21.86 & 40.57 & 0.19 & 1.04 & 0.63 & 199.8 & 585.4 \\
$(\mathrm{~N}=610)$ & Minimum & 12.10 & 14.40 & 14.10 & 15.93 & 0.00 & 0.80 & 0.27 & 7.0 & 267 \\
& Maximum & 32.60 & 30.48 & 30.18 & 79.00 & 1.71 & 2.00 & 1.22 & 1984 & 1115 \\
& Range & 20.50 & 16.08 & 16.08 & 63.07 & 1.71 & 1.20 & 0.95 & 1977 & 848 \\
& $\mathrm{SD}$ & 4.42 & 3.23 & 3.15 & 13.50 & 0.15 & 0.11 & 0.21 & 234.1 & 136.7 \\
& Error & 0.18 & 0.13 & 0.13 & .55 & 0.01 & 0.00 & 0.01 & 9.48 & 5.53 \\
\hline Moderate & Mean & 31.28 & 28.90 & 29.00 & 27.67 & 0.55 & 1.03 & 0.46 & 204.8 & 537.7 \\
(N=346) & Minimum & 21.60 & 19.50 & 20.50 & 15.40 & 0.00 & 0.80 & 0.19 & 13.0 & 147 \\
& Maximum & 37.00 & 33.80 & 34.10 & 48.30 & 3.66 & 1.60 & 0.87 & 2330 & 888 \\
& Range & 15.40 & 14.30 & 13.60 & 32.90 & 3.66 & 0.80 & 0.68 & 2317 & 741 \\
& SD & 2.77 & 3.06 & 2.87 & 6.42 & 0.47 & 0.15 & 0.13 & 213.9 & 129.2 \\
& Error & 0.15 & 0.16 & 0.15 & 0.34 & 0.03 & 0.01 & 0.01 & 11.50 & 7.13 \\
\hline Summer & Mean & 34.03 & 31.83 & 31.88 & 49.12 & 0.76 & 1.06 & 0.45 & 245.7 & 545 \\
$(\mathrm{~N}=855)$ & Minimum & 25.65 & 26.20 & 25.75 & 8.48 & 0.00 & 0.80 & 0.04 & 3.0 & 222 \\
& Maximum & 45.05 & 39.10 & 39.00 & 95.28 & 4.28 & 3.00 & 0.84 & 1997 & 1456 \\
& Range & 19.40 & 12.90 & 13.25 & 86.80 & 4.28 & 2.20 & 0.80 & 1994 & 1234 \\
& SD & 3.33 & 2.45 & 2.46 & 22.96 & 0.59 & 0.15 & 0.14 & 257.5 & 245.4 \\
& Error & 0.11 & 0.08 & 0.08 & 0.79 & 0.02 & 0.01 & 0.0 & 8.80 & 10.21
\end{tabular}

Note: $\mathrm{T}_{\mathrm{o}}$ - outdoor dry bulb temperature, $\mathrm{T}_{\mathrm{a}}$ - room air temperature, $\mathrm{T}_{\mathrm{g}}$ - globe temperature, RH - relative humidity, $\mathrm{V}_{\mathrm{a}}$ - room air velocity, Clo - clothing insulation, Met - metabolic activity, Lux - lighting intensity, $\mathrm{CO}_{2}$ - carbon dioxide, SD - standard deviation, Error standard error of mean, Range (Maximum-Minimum)

Table 4. Summary of physical characteristics of subjects

\begin{tabular}{lllll}
\hline $\mathrm{N}=1811$ & Age (years) & Height $(\mathrm{m})$ & Weight $(\mathrm{kg})$ & Body surface area $\left(\mathrm{m}^{2}\right)$ \\
Mean & 23.4 & 1.67 & 60.3 & 1.7 \\
Minimum & 16.0 & 1.0 & 35.0 & 1.1 \\
Maximum & 75.0 & 2.1 & 114.0 & 2.3 \\
Range & 59.0 & 1.1 & 79.0 & 1.3 \\
SD & 7.8 & 0.1 & 12.1 & 0.2 \\
Std. error & 0.2 & 0.0 & 0.3 & 0.0 \\
\hline
\end{tabular}


Table 5. Summary of sensation and preference variables at room conditions

\begin{tabular}{|c|c|c|c|c|c|c|c|c|}
\hline \multicolumn{2}{|l|}{$\mathrm{N}=1811$} & \multirow{2}{*}{$\begin{array}{l}\text { TS } \\
-0.84\end{array}$} & & \multirow{2}{*}{$\begin{array}{l}\text { HS } \\
-0.21\end{array}$} & \multirow{2}{*}{$\begin{array}{l}\text { HP } \\
0.00\end{array}$} & \multirow{2}{*}{$\begin{array}{l}\mathrm{VaS} \\
-0.20\end{array}$} & \multirow{2}{*}{$\begin{array}{l}\text { VaP } \\
0.11\end{array}$} & \multirow{2}{*}{$\begin{array}{l}\text { OTC } \\
3.55\end{array}$} \\
\hline Winter & Mean & & & & & & & \\
\hline \multirow[t]{5}{*}{$(\mathrm{N}=610)$} & Minimum & -3.00 & -2.00 & -3.00 & -2.00 & -3.00 & -2.00 & 1.00 \\
\hline & Maximum & 3.00 & 2.00 & 2.00 & 2.00 & 3.00 & 2.00 & 5.00 \\
\hline & Range & 6.00 & 4.00 & 5.00 & 4.00 & 6.00 & 4.00 & 4.00 \\
\hline & SD & 1.04 & 0.75 & 0.92 & 0.66 & 1.08 & 0.81 & 0.67 \\
\hline & Error & 0.04 & 0.03 & 0.04 & 0.03 & 0.04 & 0.04 & 0.03 \\
\hline Moderate & Mean & 0.36 & -0.63 & -0.27 & 0.00 & -0.14 & 0.42 & 3.43 \\
\hline \multirow[t]{5}{*}{$(\mathrm{N}=346)$} & Minimum & -2.00 & -2.00 & -3.00 & -2.00 & -3.00 & -2.00 & 1.00 \\
\hline & Maximum & 3.00 & 2.00 & 2.00 & 2.00 & 2.00 & 2.00 & 5.00 \\
\hline & Range & 5.00 & 4.00 & 5.00 & 4.00 & 5.00 & 4.00 & 4.00 \\
\hline & SD & 1.07 & 0.71 & 0.90 & 0.72 & 1.08 & 0.93 & 0.65 \\
\hline & Error & 0.06 & 0.04 & 0.05 & 0.04 & 0.06 & 0.06 & 0.03 \\
\hline Summer & Mean & 0.73 & -0.91 & 0.49 & -0.37 & -0.04 & 0.51 & 3.13 \\
\hline \multirow[t]{5}{*}{$(\mathrm{N}=855)$} & Minimum & -2.00 & -2.00 & -3.00 & -2.00 & -3.00 & -2.00 & 1.00 \\
\hline & Maximum & 3.00 & 1.00 & 3.00 & 2.00 & 3.00 & 2.00 & 5.00 \\
\hline & Range & 5.00 & 3.00 & 6.00 & 4.00 & 6.00 & 4.00 & 4.00 \\
\hline & SD & 1.19 & 0.66 & 1.24 & 0.87 & 1.15 & 0.86 & 0.78 \\
\hline & Error & 0.04 & 0.02 & 0.04 & 0.03 & 0.04 & 0.04 & 0.03 \\
\hline All season & Mean & 0.13 & -0.41 & 0.11 & -0.18 & -0.11 & 0.33 & 3.33 \\
\hline \multirow[t]{5}{*}{$(\mathrm{N}=1811)$} & Minimum & -3.00 & -2.00 & -3.00 & -2.00 & -3.00 & -2.00 & 1.00 \\
\hline & Maximum & 3.00 & 2.00 & 3.00 & 2.00 & 3.00 & 2.00 & 5.00 \\
\hline & Range & 6.00 & 4.00 & 6.00 & 4.00 & 6.00 & 4.00 & 4.00 \\
\hline & SD & 1.32 & 0.92 & 1.14 & 0.80 & 1.12 & 0.87 & 0.74 \\
\hline & Error & 0.03 & 0.02 & 0.03 & 0.02 & 0.03 & 0.03 & 0.02 \\
\hline
\end{tabular}

Note: TS -Thermal Sensation, TP -Thermal Preference, HS - Humidity Sensation, HP Humidity Preference, VaS - Air Velocity Sensation, VaP - Air Velocity Preference, OTC Overall Thermal Comfort 
Table 6. Summary of seasonal variations in thermal neutrality

\begin{tabular}{llllll}
\hline S No & Parameter & $\begin{array}{l}\text { Combined data } \\
(\text { Year round) }\end{array}$ & $\begin{array}{l}\text { Winter } \\
\text { season }\end{array}$ & $\begin{array}{l}\text { Moderate } \\
\text { season }\end{array}$ & $\begin{array}{l}\text { Summer } \\
\text { season }\end{array}$ \\
\hline 1 & $\begin{array}{l}\text { Regression } \\
\text { equation }\end{array}$ & $\begin{array}{l}\mathrm{TS}_{\mathrm{C}}= \\
0.169 \mathrm{~T}_{\mathrm{a}}-4.598\end{array}$ & $\begin{array}{l}\mathrm{TS}_{\mathrm{w}}= \\
0.171 \mathrm{~T}_{\mathrm{a}}-4.386\end{array}$ & $\begin{array}{l}\mathrm{TS}_{\mathrm{M}}= \\
0.144 \mathrm{~T}_{\mathrm{a}}-3.888\end{array}$ & $\begin{array}{l}\mathrm{TS}_{\mathrm{S}}= \\
0.299 \mathrm{~T}_{\mathrm{a}}- \\
\end{array}$ \\
& & & & 8.788 \\
2 & Neutral & $27.21{ }^{\circ} \mathrm{C}$ & $25.64{ }^{\circ} \mathrm{C}$ & $27.0{ }^{\circ} \mathrm{C}$ & $29.40{ }^{\circ} \mathrm{C}$ \\
& temp. & & & & \\
3 & $\mathrm{R}$ & 0.711 & 0.448 & 0.338 & 0.612 \\
4 & $\mathrm{R}^{2}$ & 0.506 & 0.201 & 0.114 & 0.375 \\
\hline
\end{tabular}

Note: $\mathrm{TS}_{\mathrm{C}}, \mathrm{TS}_{\mathrm{W}}, \mathrm{TS}_{\mathrm{M}}$, and $\mathrm{TS}_{\mathrm{S}}$ represent thermal sensation for combined, winter, moderate and thermal sensation for summer season. $\mathrm{R}^{2}$ - Coefficient of determination, $\mathrm{R}$ - Regression coefficient, TS - thermal sensation 

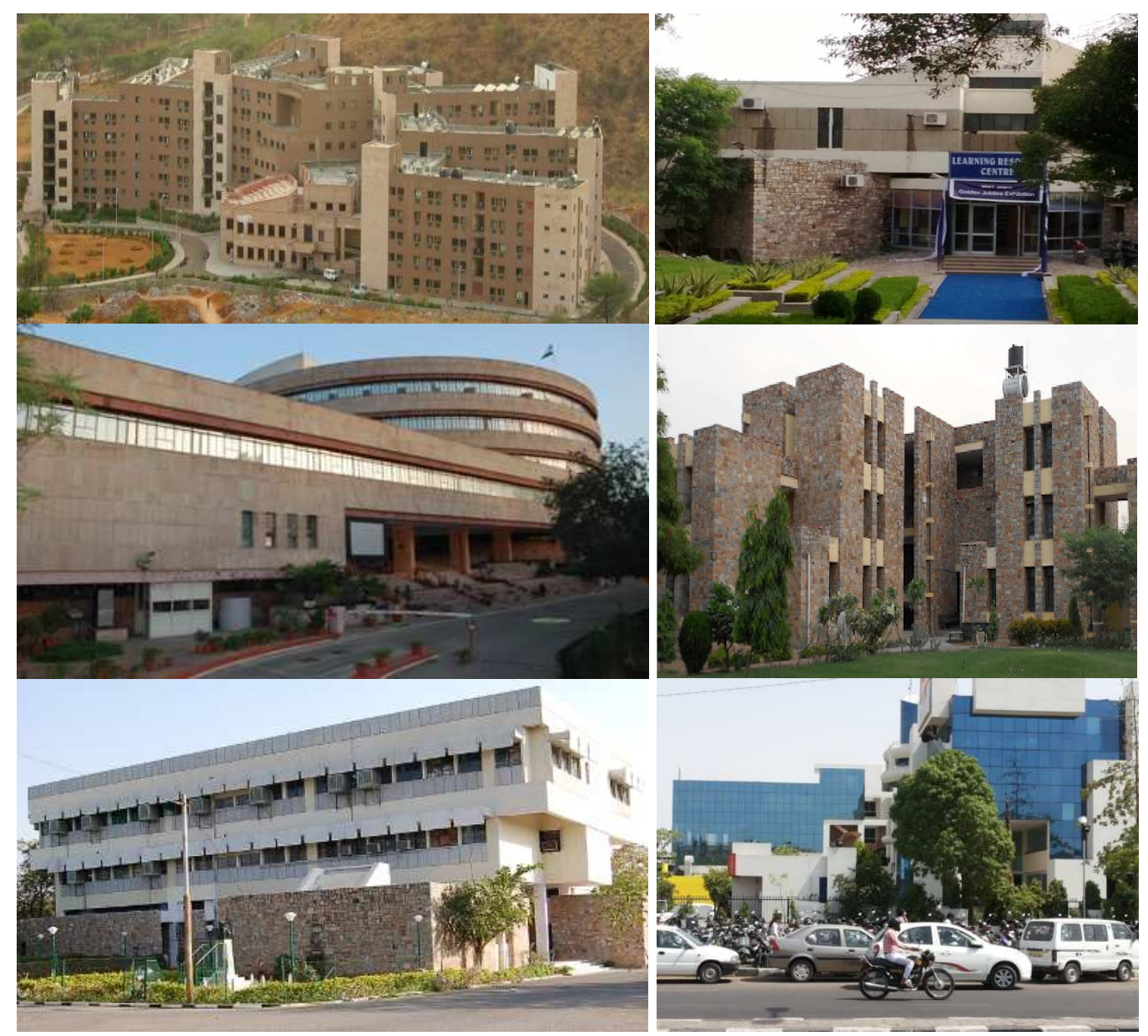

Fig.1. Photographs of buildings chosen for the field study of thermal comfort

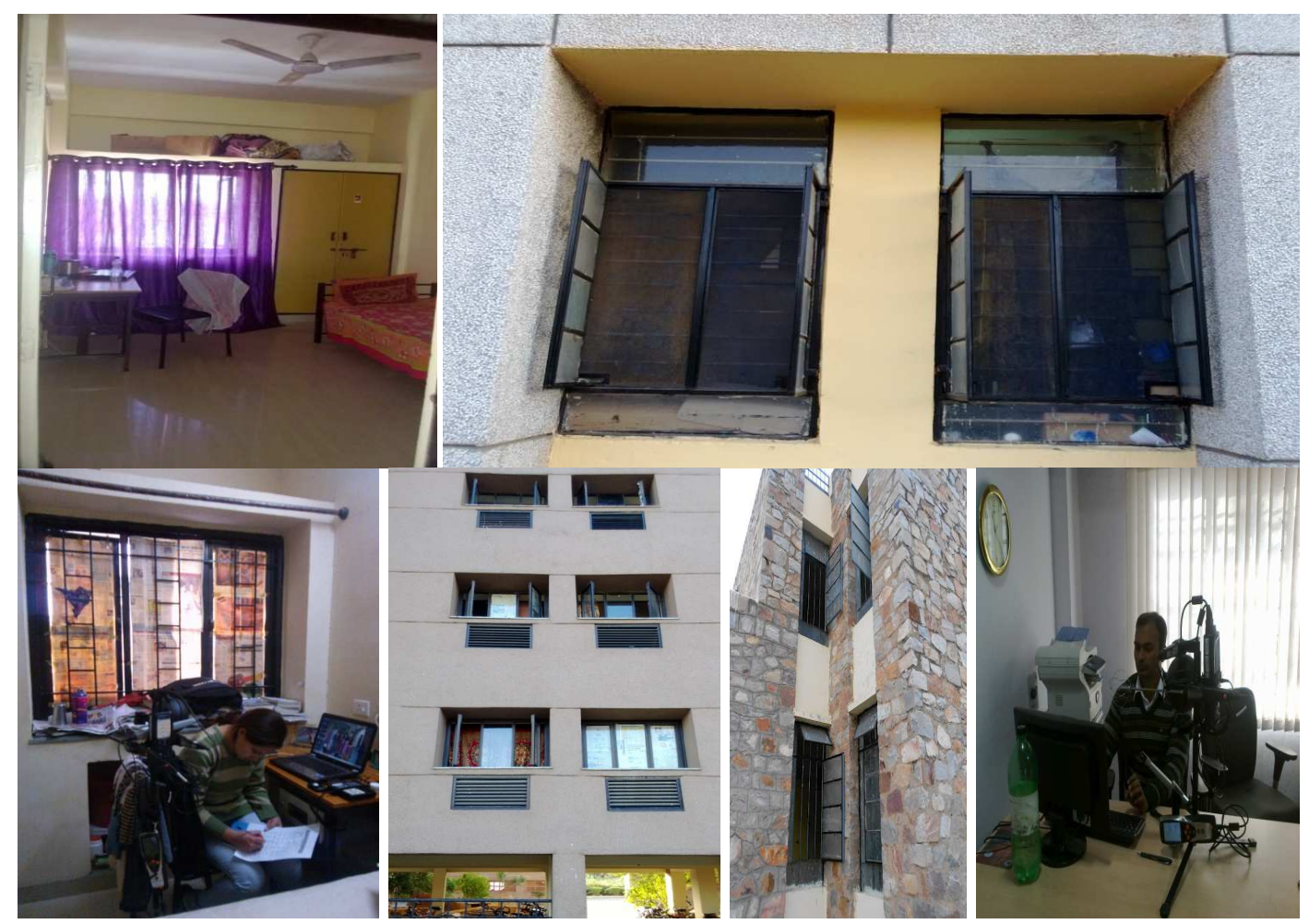

Fig.2. Control conditions and survey environment in the subject buildings 


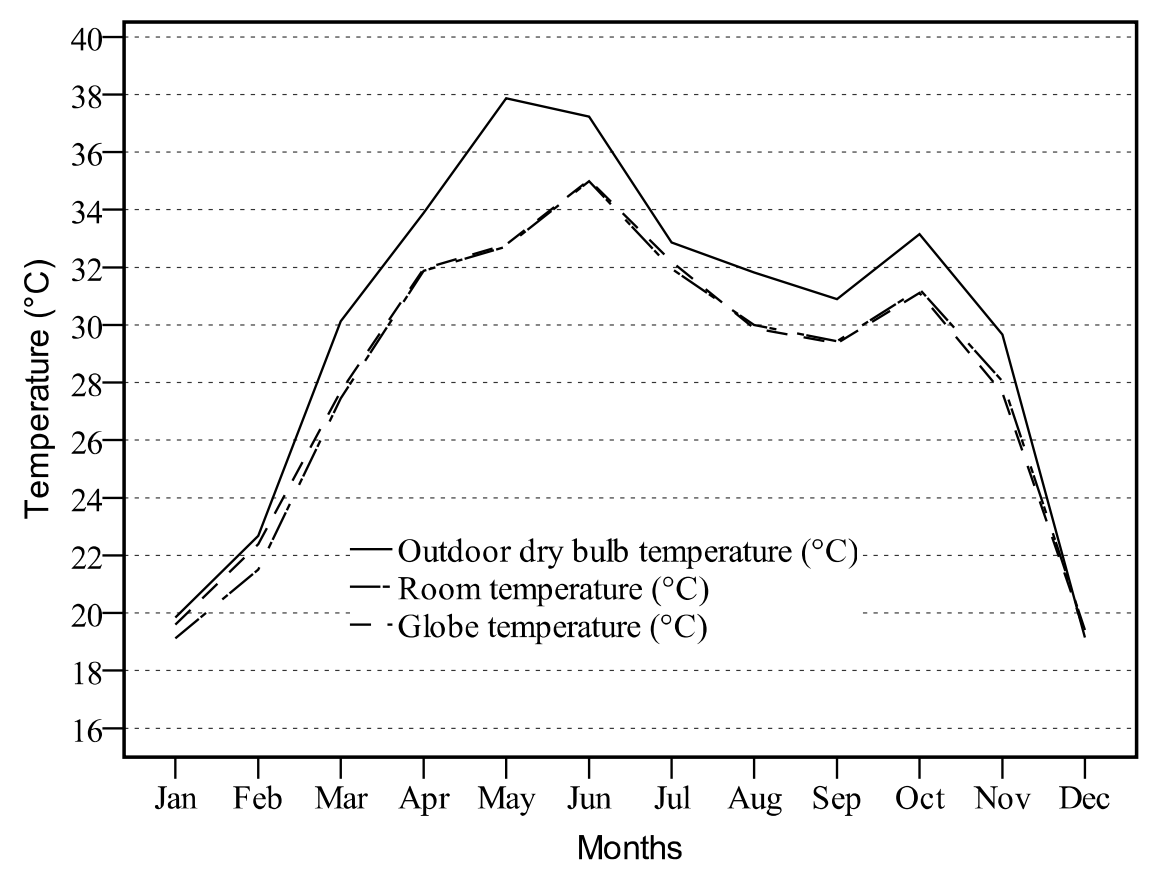

Fig.3. Monthly variation in indoor and outdoor temperatures

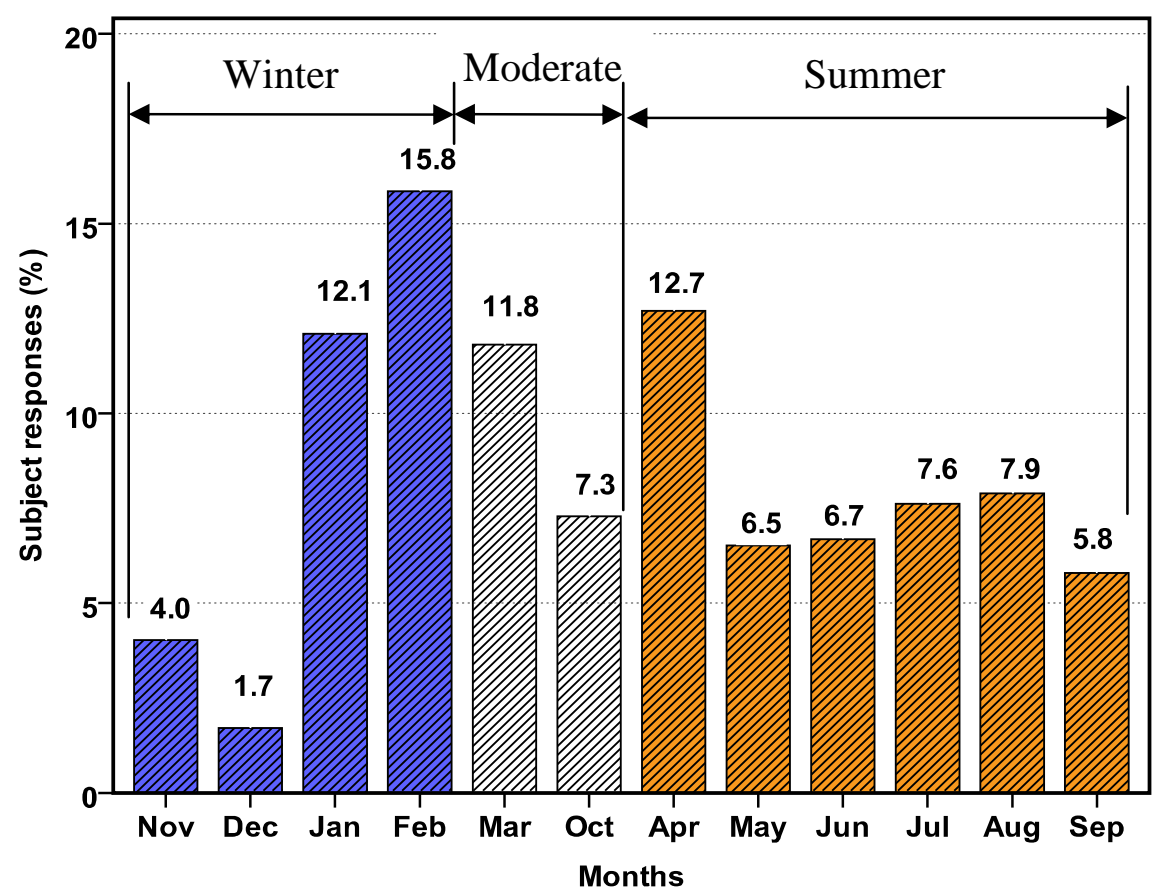

Fig.4. Monthly distribution of subject responses 


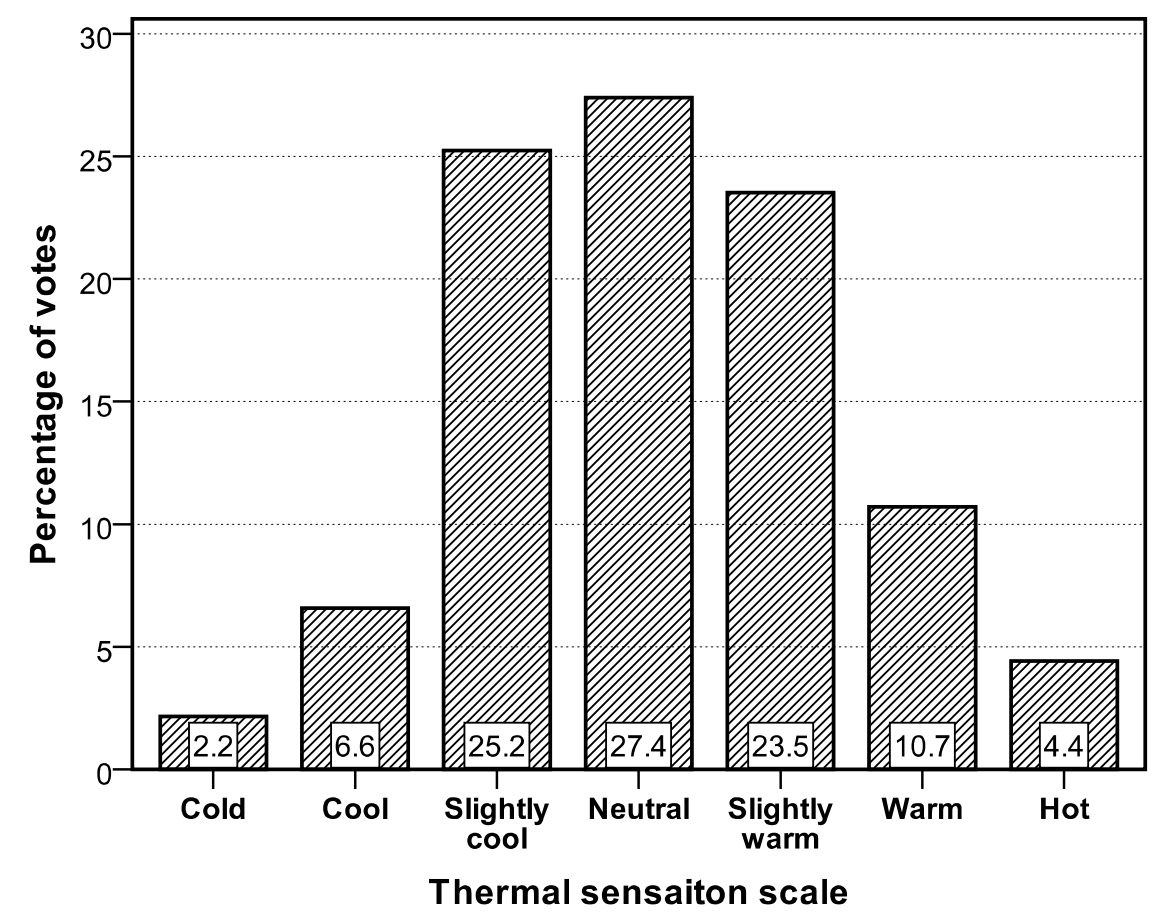

Fig.5. Thermal sensation votes on ASHRAE's seven-point scale

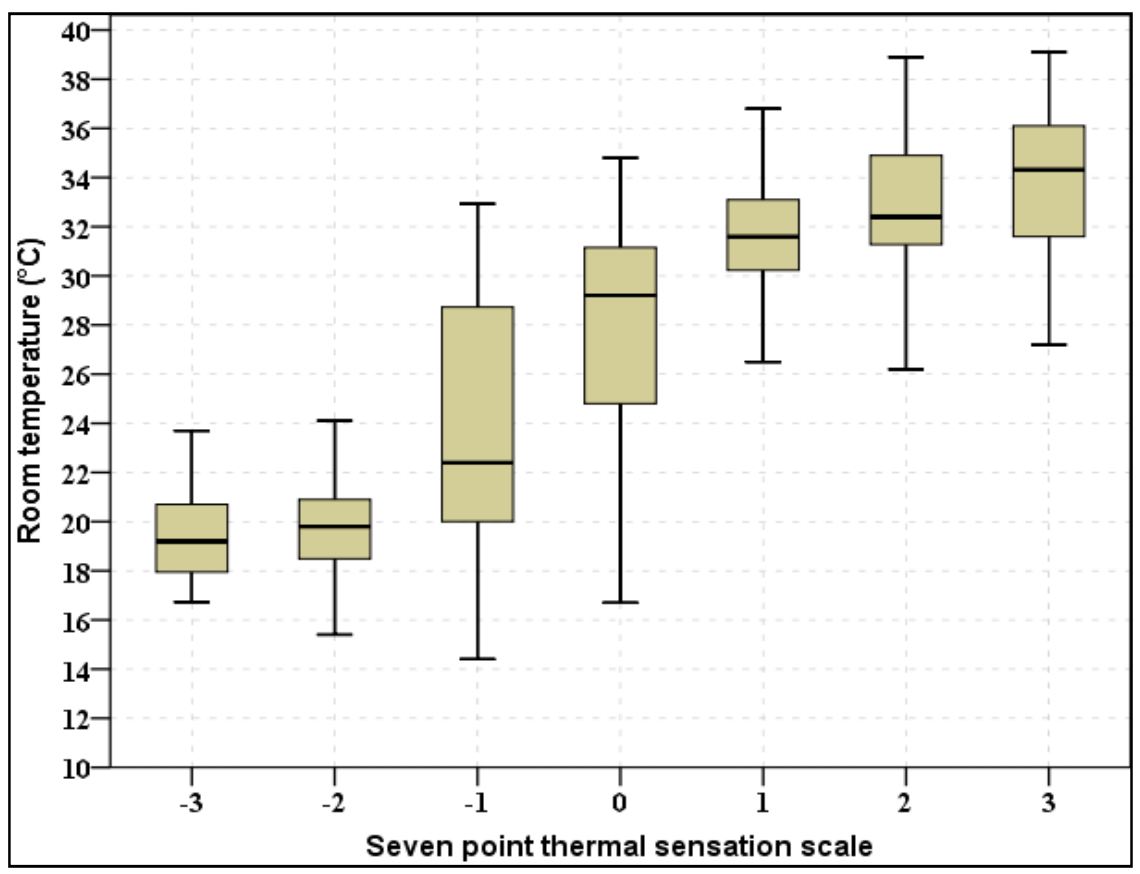

Fig.6. Distribution of thermal sensation votes over room temperatures 


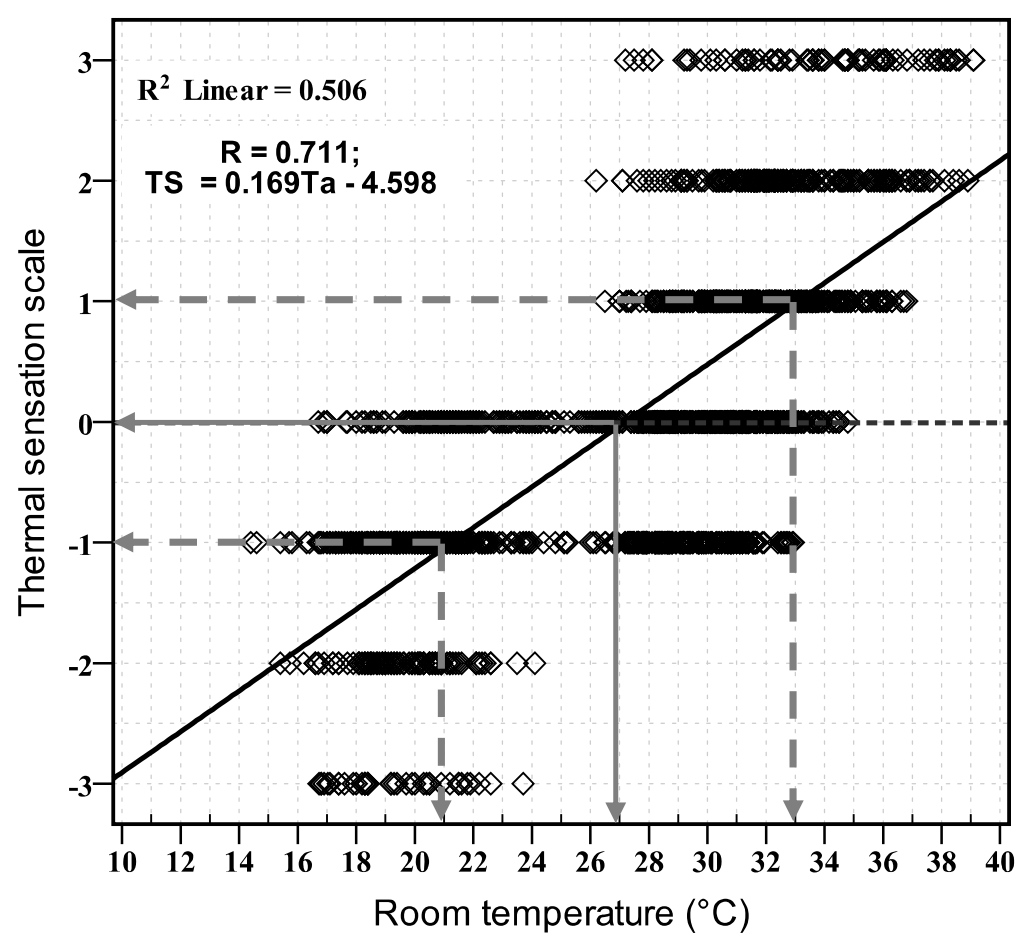

Fig.7. Regression plot between thermal sensation votes and room temperatures

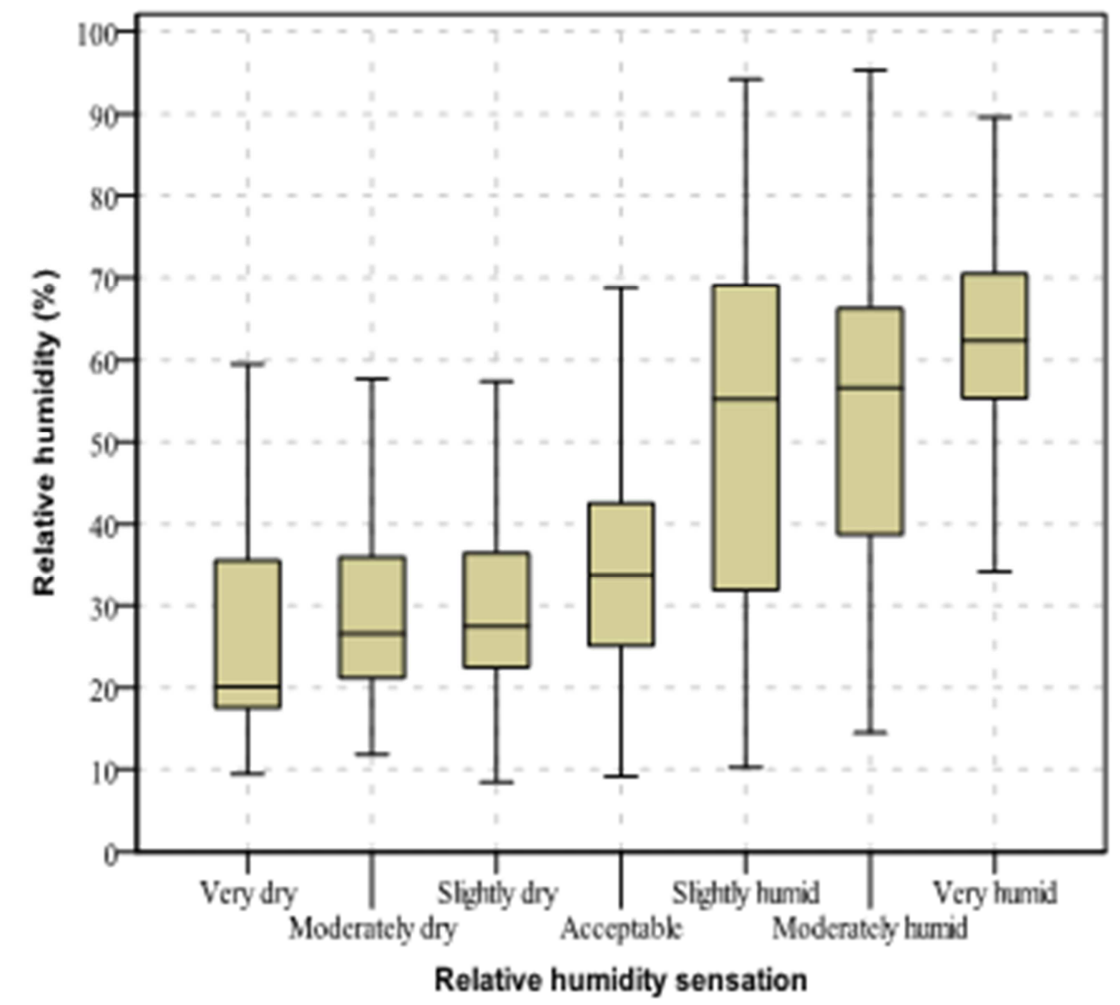

Fig.8. Variations in humidity sensation votes over relative humidity 


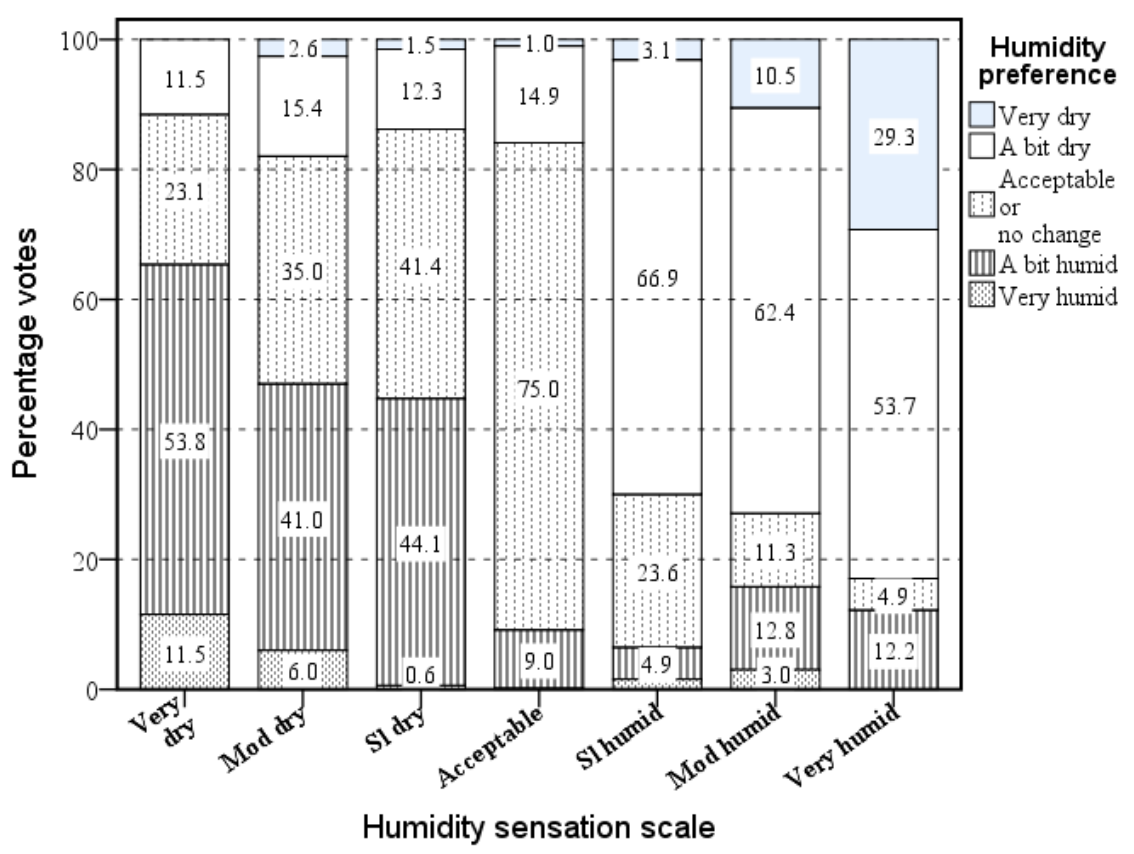

Fig.9. Tabulated summary of humidity preference votes on humidity sensation scale

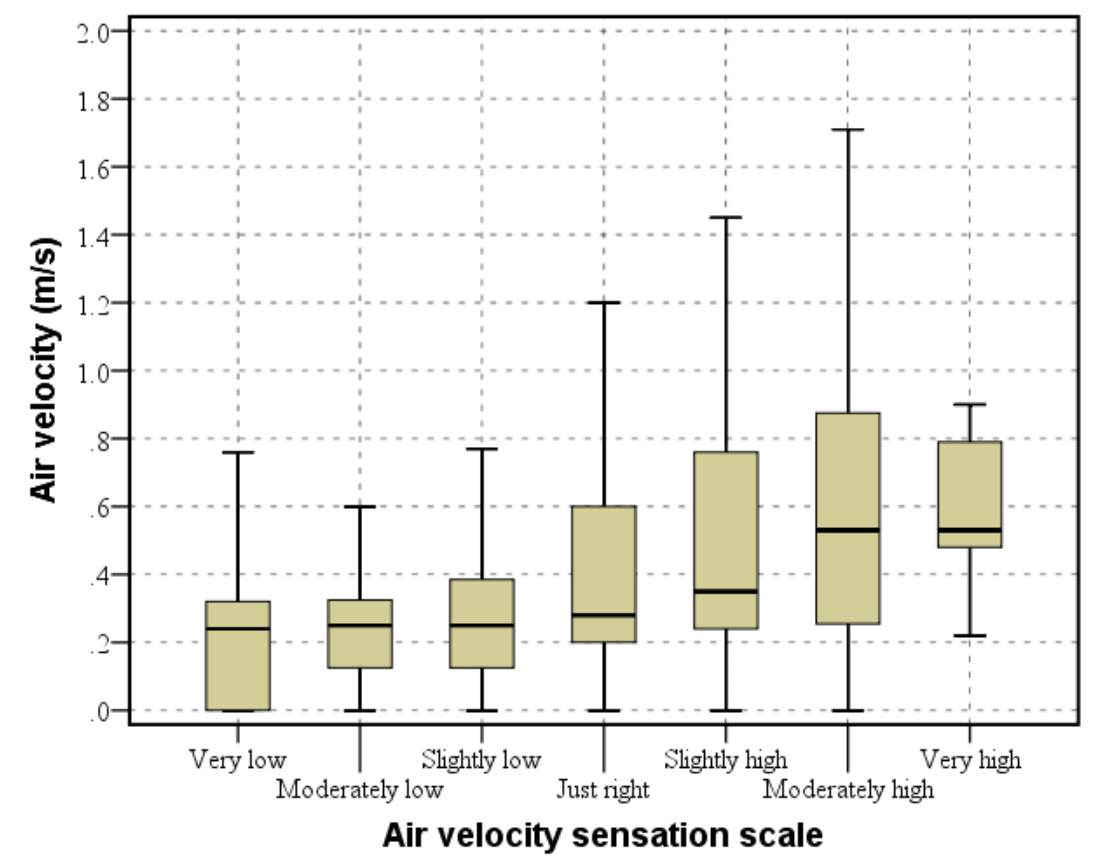

Fig.10. Box plot between air velocity sensation votes and room air velocity 


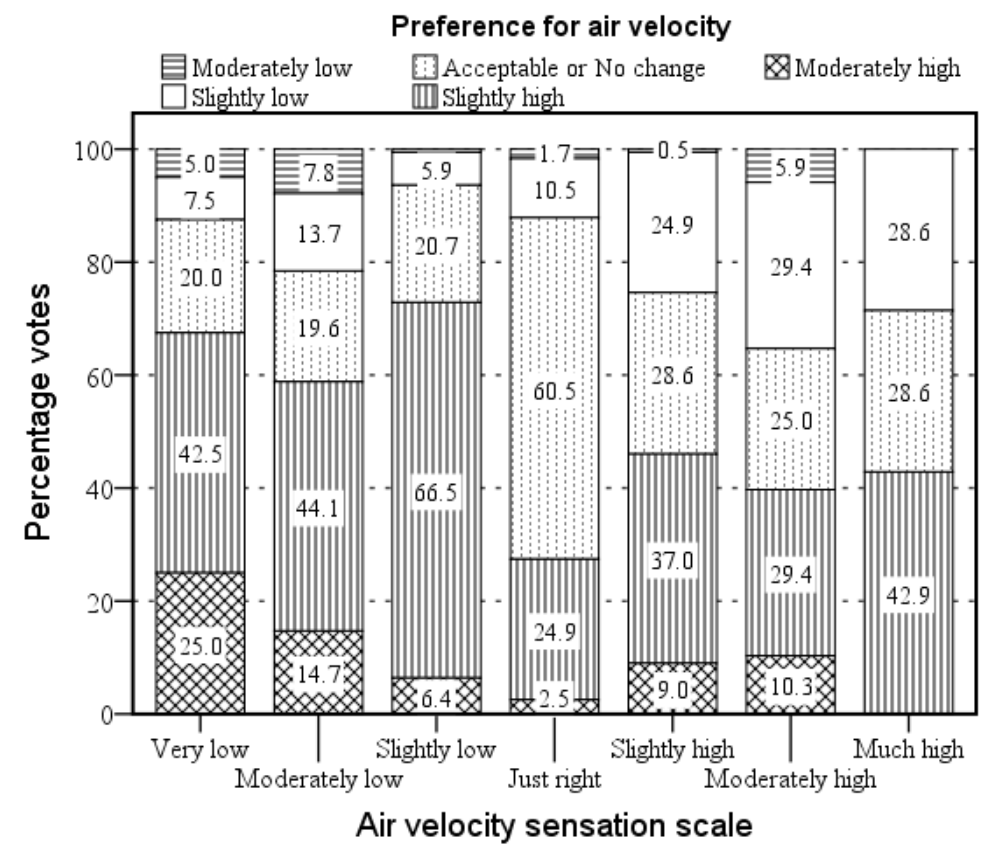

Fig.11. Tabular summary between air velocity sensation and air velocity preference

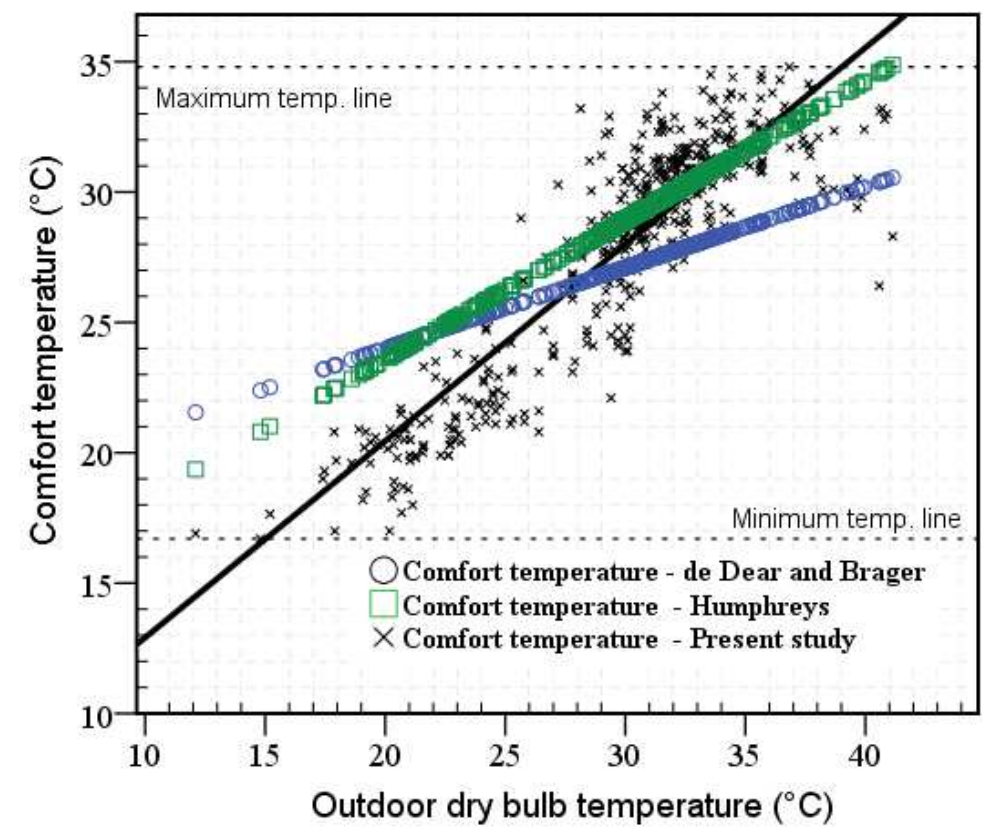

Fig.12. Comparison of comfort temperature for present study and previous studies of thermal comfort 

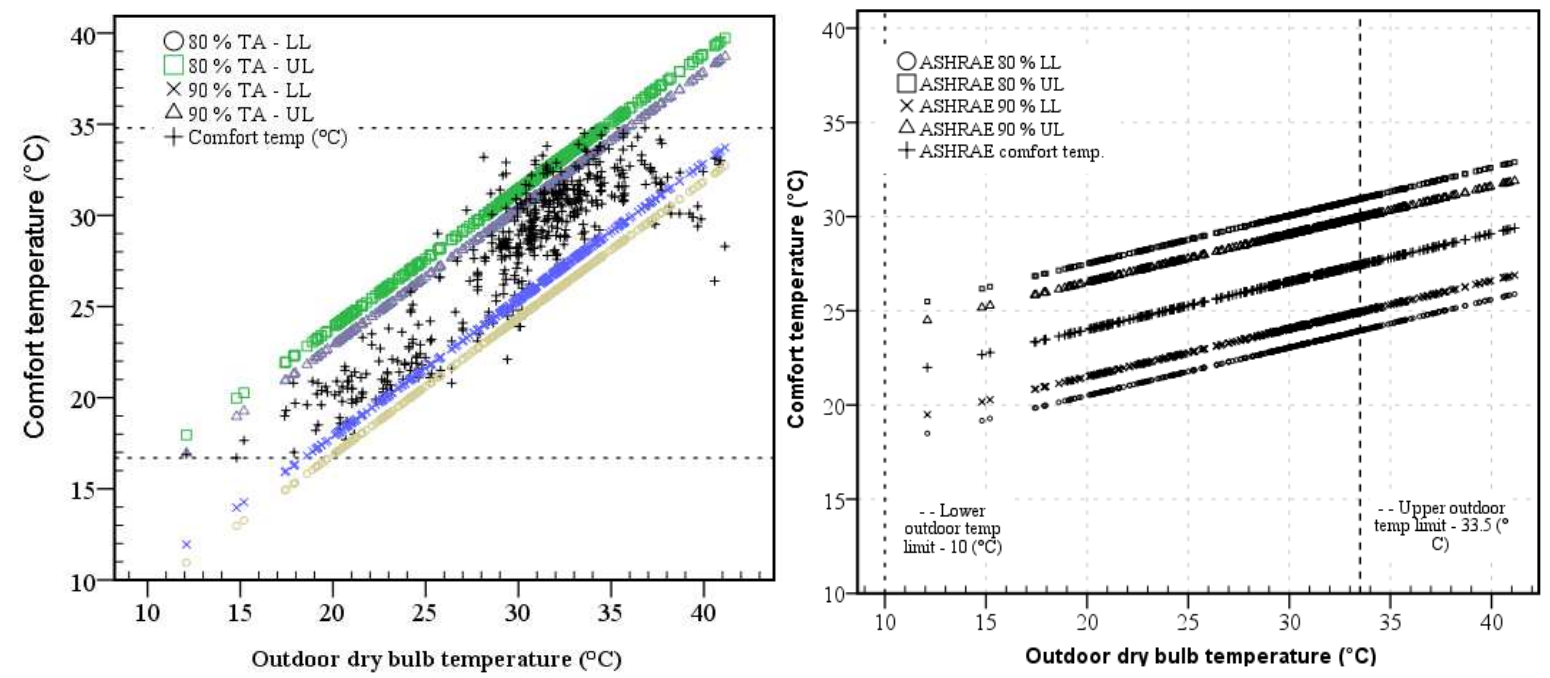

Fig.13.90\% and 80\% acceptability for present study (a) acceptability for naturally ventilated buildings as per ASHRAE Standard 55 (b)

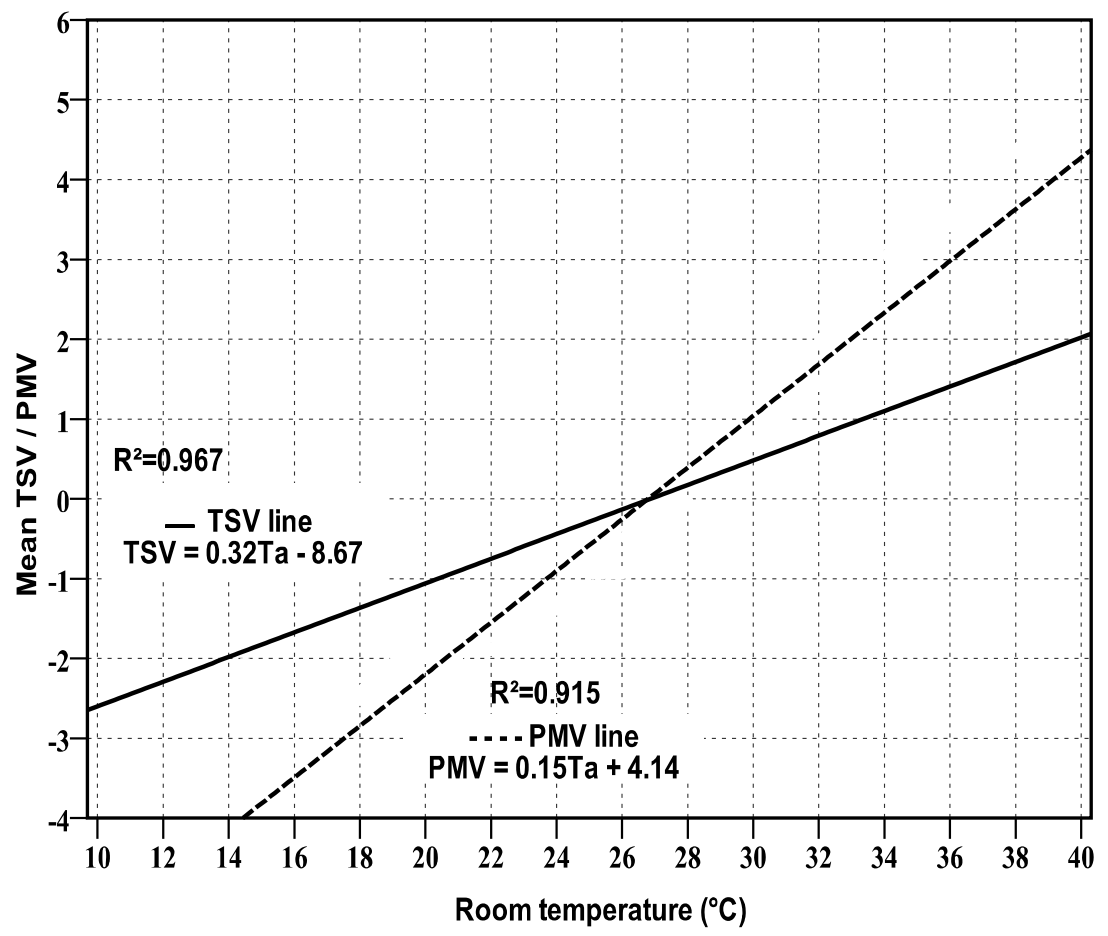

Fig.14. Comparison between thermal sensation votes and PMV index 